Article

\title{
Solvent-Dependent Structures of Natural Products Based on the Combined Use of DFT Calculations and ${ }^{1}$ H-NMR Chemical Shifts
}

\author{
Saima H. Mari ${ }^{1}$, Panayiotis C. Varras ${ }^{2}$, Atia-tul-Wahab ${ }^{3, *}$, Iqbal M. Choudhary ${ }^{1,3}$, \\ Michael G. Siskos ${ }^{2}$ and Ioannis P. Gerothanassis $1,2,3, *$ \\ 1 H.E.J. Research Institute of chemistry, International Center for Chemical and Biological Sciences, University \\ of Karachi, Karachi 7527, Pakistan; Saimahassanmari123@gmail (S.H.M.); iqbal.choudhary@iccs.edu (I.M.C.) \\ 2 Section of Organic Chemistry \& Biochemistry, Department of Chemistry, University of Ioannina, \\ GR-45110 Ioannina, Greece; panostch@gmail.com (P.C.V.); msiskos@uoi.gr (M.G.S.) \\ 3 Dr. Panjwani Center for Molecular Medicine and Drug Research, International Center for Chemical and \\ Biological Sciences, University of Karachi, Karachi 7527, Pakistan \\ * Correspondence: Atiatulwahab@gmail.com (A.-t.-W.); igeroth@uoi.gr (I.P.G.)
}

Academic Editor: Raquel P. Herrera

Received: 30 May 2019; Accepted: 18 June 2019; Published: 20 June 2019

check for updates

\begin{abstract}
Detailed solvent and temperature effects on the experimental ${ }^{1} \mathrm{H}-\mathrm{NMR}$ chemical shifts of the natural products chrysophanol (1), emodin (2), and physcion (3) are reported for the investigation of hydrogen bonding, solvation and conformation effects in solution. Very small chemical shift of $|\Delta \delta|<0.3 \mathrm{ppm}$ and temperature coefficients $|\Delta \delta / \Delta \mathrm{T}| \leq 2.1 \mathrm{ppb} / \mathrm{K}$ were observed in DMSO- $\mathrm{d}_{6}$, acetone- $\mathrm{d}_{6}$ and $\mathrm{CDCl}_{3}$ for the $\mathrm{C}(1)-\mathrm{OH}$ and $\mathrm{C}(8)-\mathrm{OH}$ groups which demonstrate that they are involved in a strong intramolecular hydrogen bond. On the contrary, large chemical shift differences of $5.23 \mathrm{ppm}$ at $298 \mathrm{~K}$ and $\Delta \delta / \Delta \mathrm{T}$ values in the range of -5.3 to $-19.1 \mathrm{ppb} / \mathrm{K}$ between DMSO- $\mathrm{d}_{6}$ and $\mathrm{CDCl}_{3}$ were observed for the $\mathrm{C}(3)-\mathrm{OH}$ group which demonstrate that the solvation state of the hydroxyl proton is a key factor in determining the value of the chemical shift. DFT calculated ${ }^{1} \mathrm{H}-\mathrm{NMR}$ chemical shifts, using various functionals and basis sets, the conductor-like polarizable continuum model, and discrete solute-solvent hydrogen bond interactions, were found to be in very good agreement with the experimental ${ }^{1} \mathrm{H}-\mathrm{NMR}$ chemical shifts even with computationally less demanding level of theory. The ${ }^{1} \mathrm{H}-\mathrm{NMR}$ chemical shifts of the $\mathrm{OH}$ groups which participate in intramolecular hydrogen bond are dependent on the conformational state of substituents and, thus, can be used as molecular sensors in conformational analysis. When the X-ray structures of chrysophanol (1), emodin (2), and physcion (3) were used as input geometries, the DFT-calculated ${ }^{1} \mathrm{H}-\mathrm{NMR}$ chemical shifts were shown to strongly deviate from the experimental chemical shifts and no functional dependence could be obtained. Comparison of the most important intramolecular data of the DFT calculated and the X-ray structures demonstrate significant differences for distances involving hydrogen atoms, most notably the intramolecular hydrogen bond $\mathrm{O}-\mathrm{H}$ and $\mathrm{C}-\mathrm{H}$ bond lengths which deviate by 0.152 to $0.132 \AA$ and 0.133 to $0.100 \AA$, respectively, in the two structural methods. Further differences were observed in the conformation of $-\mathrm{OH},-\mathrm{CH}_{3}$, and $-\mathrm{OCH}_{3}$ substituents.
\end{abstract}

Keywords: chemical shifts; hydrogen bonding; DFT; natural products; NMR; X-ray diffraction

\section{Introduction}

The single-crystal X-ray diffraction has been the most widely used method for structural analysis in the solid state [1-3]. In macromolecular crystallography, it may be argued that the structural data bears some resemblance to the solution structure, since the crystals frequently contain significant 
numbers of solvent molecules, usually water [4,5]. In organic chemistry crystallography, however, the incorporation of solvent molecules can be, in most cases, very limited. Extrapolation, therefore, of the molecular conformation in the crystal to possible conformations in solution, is very problematic since crystal packing interactions can stabilize conformers that are rarely encountered in solution.

NMR spectroscopy is among the primary methods for investigating structure and dynamics of complex molecules in solution [6]. Several NMR parameters such as chemical shifts [7-9], temperature and solvent effects on chemical shifts [10,11], the NOE phenomenon [12,13], and spin-spin couplings $[6,14,15]$ have been utilized in order to establish empirical correlation with structural data. The development of quantum chemical methods for calculating NMR parameters, with emphasis on chemical shifts, as well as advances in computational techniques and computer power, have led to an increasing number of studies that combine calculation with experiment [16-20]. Several examples of using computed NMR chemical shifts to confirm proposed structures or to aid the reassignment of structures can be found in the literature [20-25]. To date, however, only a handful examples of organic molecules whose structures have been determined by both computation of NMR chemical shifts in solution and X-ray were reported [26-31]. Furthermore, to the best of our knowledge, no solvent-dependent DFT structures have so far been reported, thus, there is no sufficient experimental basis for assessing the accuracy of NMR solution structures.

Herein, a comparison of the solvent-dependent structures, based on the combined use of DFT calculations and ${ }^{1} \mathrm{H}-\mathrm{NMR}$ chemical shifts, and the single-crystal X-ray structures of three natural products, chrysophanol (1), emodin (2), and physcion (3) (Scheme 1), are reported in order to quantify the degree of similarity/ difference between the results obtained with these two structural methods and to ascertain the molecular and electronic origin of the differences. The three molecules selected belong to the anthraquinone family. Chrysophanol (1), also known as chrysophanic acid, was identified as a fungal metabolite which blocks the proliferation of colon cancer cells in vitro [32]. Emodin (2), derived from Rheum emodi (Himalyan rhubarb), possess a wide range of anticancer, anti-oxidant, hepatoprotective, anti-inflammatory and anti-microbial properties [33,34]. Physcion (3), also known as parietin, is a predominant cortical pigment of lichens in the genus Caloploca. Physcion (3) from marine-derived fungus Microsporum sp. was reported to induce apoptosis in human cervical carcinoma HeLa cells [35].<smiles>COc1cc2c3c(c1)C(=O)c1cc(C)cc4c1C31OCOCC1OCOc1cc(O)cc(c1-4)C2=O</smiles>

(1)

(2)

(3)

Scheme 1. Chemical structures of the compounds investigated in the present work: chrysophanol (1), emodin (2), and physcion (3).

\section{Results and Discussion}

\subsection{Experimental ${ }^{1} H-N M R$ Chemical Shifts}

\subsubsection{Assignment of the Resonances}

For the investigation of solvent and temperature effects on the ${ }^{1} \mathrm{H}-\mathrm{NMR}$ resonances, the unequivocal assignment of the resonances of the molecules under study should be achieved. The 1D ${ }^{1} \mathrm{H}-\mathrm{NMR}$ spectra of chrysophanol (1), emodin (2), and physcion (3) show extremely deshielded and sharp peaks which are attributed to the $\mathrm{C}(1)-\mathrm{OH}$ and $\mathrm{C}(8)-\mathrm{OH}$ protons (Table 1 ) which participate in a 
strong intramolecular hydrogen bond with the $\mathrm{O}=\mathrm{C}(9)$ carbonyl oxygen atom. The planar configuration of the two six membered rings results in a significant deshielding [8,36-42] and reduction of the $\mathrm{OH}$ proton exchange rates [36-42]. This allowed the application of the ${ }^{1} \mathrm{H}-{ }^{13} \mathrm{C}$ HMBC NMR experiments to reveal long-range ${ }^{\mathrm{n}} \mathrm{J}\left({ }^{13} \mathrm{C},{ }_{1}^{1} \mathrm{H}\right)$ connectivities (Supplementary materials, Figure S1, Table S1), thus, providing an unequivocal assignment of the $\mathrm{C}(1)-\mathrm{OH}$ and $\mathrm{C}(8)-\mathrm{OH}$ groups. The assignments of the ${ }^{1} \mathrm{H}-\mathrm{NMR}$ chemical shifts were, furthermore, confirmed by 1D-NOE and 1D-TOCSY experiments.

Table 1. ${ }^{1} \mathrm{H}-\mathrm{NMR}$ chemical shifts, $\delta$ (ppm), of chrysophanol (1), emodin (2), and physcion (3), in $\mathrm{CDCl}_{3}$, acetone- $\mathrm{d}_{6}$, and DMSO- $\mathrm{d}_{6}$ and their differences at $298 \mathrm{~K}$.

\begin{tabular}{|c|c|c|c|c|c|c|}
\hline Compound & Group & $\delta_{\mathrm{CDCl}_{3}}$ & $\delta_{\text {acetone- } \mathrm{d}_{6}}$ & $\begin{array}{c}\Delta \delta \\
\left(\delta_{\text {acetone- } \mathrm{d}_{6}}-\delta_{\mathrm{CDCl}_{3}}\right)\end{array}$ & $\delta_{\mathrm{DMSO}^{-} \mathrm{d}_{6}}$ & $\begin{array}{c}\Delta \delta \\
\left(\delta_{\text {DMSO- }_{6}}-\delta_{\mathrm{CDCl}_{3}}\right)\end{array}$ \\
\hline \multirow{8}{*}{ Chrysophanol (1) } & $\mathrm{C}(1)-\mathrm{OH}$ & 12.11 & 12.03 & -0.08 & 11.96 & -0.15 \\
\hline & $\mathrm{C}(8)-\mathrm{OH}$ & 12.00 & 11.95 & -0.05 & 11.87 & -0.13 \\
\hline & $\mathrm{C}(4)-\mathrm{H}$ & 7.64 & 7.62 & -0.02 & 7.56 & -0.08 \\
\hline & $\mathrm{C}(5)-\mathrm{H}$ & 7.81 & 7.70 & -0.11 & 7.71 & -0.10 \\
\hline & $\mathrm{C}(3)-\mathrm{H}$ & 7.65 & 7.82 & 0.17 & 7.80 & 0.15 \\
\hline & $\mathrm{C}(7)-\mathrm{H}$ & 7.27 & 7.35 & 0.08 & 7.38 & 0.11 \\
\hline & $\mathrm{C}(2)-\mathrm{H}$ & 7.09 & 7.19 & 0.10 & 7.22 & 0.13 \\
\hline & $\mathrm{C}(6)-\mathrm{CH}_{3}$ & 2.45 & 2.45 & 0.00 & 2.44 & -0.01 \\
\hline \multirow{8}{*}{ Emodin (2) } & $\mathrm{C}(1)-\mathrm{OH}$ & 12.26 & 12.21 & -0.05 & 12.11 & -0.15 \\
\hline & $\mathrm{C}(8)-\mathrm{OH}$ & 12.08 & 12.09 & 0.01 & 12.04 & -0.04 \\
\hline & $\mathrm{C}(5)-\mathrm{H}$ & 7.61 & 7.58 & -0.03 & 7.50 & -0.11 \\
\hline & $\mathrm{C}(4)-\mathrm{H}$ & 7.26 & 7.27 & 0.01 & 7.18 & -0.08 \\
\hline & $\mathrm{C}(7)-\mathrm{H}$ & 7.07 & 7.15 & 0.08 & 7.11 & 0.04 \\
\hline & $\mathrm{C}(2)-\mathrm{H}$ & 6.65 & 6.67 & 0.02 & 6.57 & -0.08 \\
\hline & $\mathrm{C}(3)-\mathrm{OH}$ & 6.18 & 10.21 & 4.03 & 11.41 & 5.23 \\
\hline & $\mathrm{C}(6)-\mathrm{CH}_{3}$ & 2.41 & 2.47 & 0.06 & 2.41 & 0.00 \\
\hline \multirow{8}{*}{ Physcion (3) } & $\mathrm{C}(1)-\mathrm{OH}$ & 12.30 & 12.24 & -0.06 & 12.17 & -0.13 \\
\hline & $\mathrm{C}(8)-\mathrm{OH}$ & 12.10 & 12.05 & -0.05 & 11.97 & -0.13 \\
\hline & $\mathrm{C}(2)-\mathrm{H}$ & 6.67 & 6.80 & 0.13 & 6.68 & 0.01 \\
\hline & $\mathrm{C}(4)-\mathrm{H}$ & 7.35 & 7.28 & -0.07 & 7.20 & -0.15 \\
\hline & $\mathrm{C}(5)-\mathrm{H}$ & 7.61 & 7.59 & -0.02 & 7.53 & -0.08 \\
\hline & $\mathrm{C}(7)-\mathrm{H}$ & 7.06 & 7.16 & 0.10 & 7.20 & 0.14 \\
\hline & $\mathrm{C}(3)-\mathrm{OCH}_{3}$ & 3.92 & 4.00 & 0.08 & 3.92 & 0.00 \\
\hline & $\mathrm{C}(6)-\mathrm{CH}_{3}$ & 2.43 & 2.47 & 0.04 & 2.42 & -0.01 \\
\hline
\end{tabular}

\subsubsection{Solvent Effects on ${ }^{1} \mathrm{H}-\mathrm{NMR}$ Chemical Shifts}

Three solvents, $\mathrm{CDCl}_{3}(\varepsilon=4.81)$, acetone- $\mathrm{d}_{6}(\varepsilon=20.7)$ and DMSO- $\mathrm{d}_{6}(\varepsilon=46.7)$ with significantly different dielectric constants, solvation and hydrogen bonding ability were selected to investigate the effect of solvents on intra- and inter- molecular hydrogen bond and conformation of the three natural products. The experimental data are reported in Table 1 using the same experimental conditions i.e., dilute solutions with concentration $\leq 2 \mathrm{mM}$ at $298 \mathrm{~K}$. The results clearly demonstrate that the $\mathrm{C}(1)-\mathrm{OH}$ and $\mathrm{C}(8)-\mathrm{OH}$ groups are involved in strong intramolecular hydrogen bond which is not affected by the solvent even in the case of DMSO, which is a solvent of high dielectric constant and solvation ability. Due to strong intramolecular hydrogen bond, the solvent molecules around the $\mathrm{C}(1)-\mathrm{OH}$ and $\mathrm{C}(8)-\mathrm{OH}$ protons are excluded, leading to a significantly reduced solvation and, thus, very small chemical shift solvent-dependence.

The C(3)-OH resonance of emodin (2) was found to be extremely broad and could hardly be distinguished from the baseline, contrary to the case of the $\mathrm{C}(1)-\mathrm{OH}$ and $\mathrm{C}(8)-\mathrm{OH}$ groups which participate in a strong intramolecular hydrogen bond. Addition of $2 \mu \mathrm{L}$ of trifluoroacetic acid (TFA) resulted in very sharp resonances which allowed the accurate estimation of chemical shifts in DMSO- $\mathrm{d}_{6}$ and acetone- $\mathrm{d}_{6}$ (Figure 1). The resulting chemical shifts in DMSO- $\mathrm{d}_{6}(\delta=11.41)$, acetone- $\mathrm{d}_{6}(\delta=10.21)$ and $\mathrm{CDCl}_{3}(\delta=6.18)$ clearly indicate that hydrogen bond between the $\mathrm{C}(3)-\mathrm{OH}$ group and $\mathrm{DMSO}-\mathrm{d}_{6}$ is more efficient than in acetone- $\mathrm{d}_{6}$ and significantly stronger than in $\mathrm{CDCl}_{3}$. This demonstrates the great sensitivity of ${ }^{1} \mathrm{H}-\mathrm{NMR}$ chemical shifts to both intra- and intermolecular hydrogen bond [26-30,40-48]. 

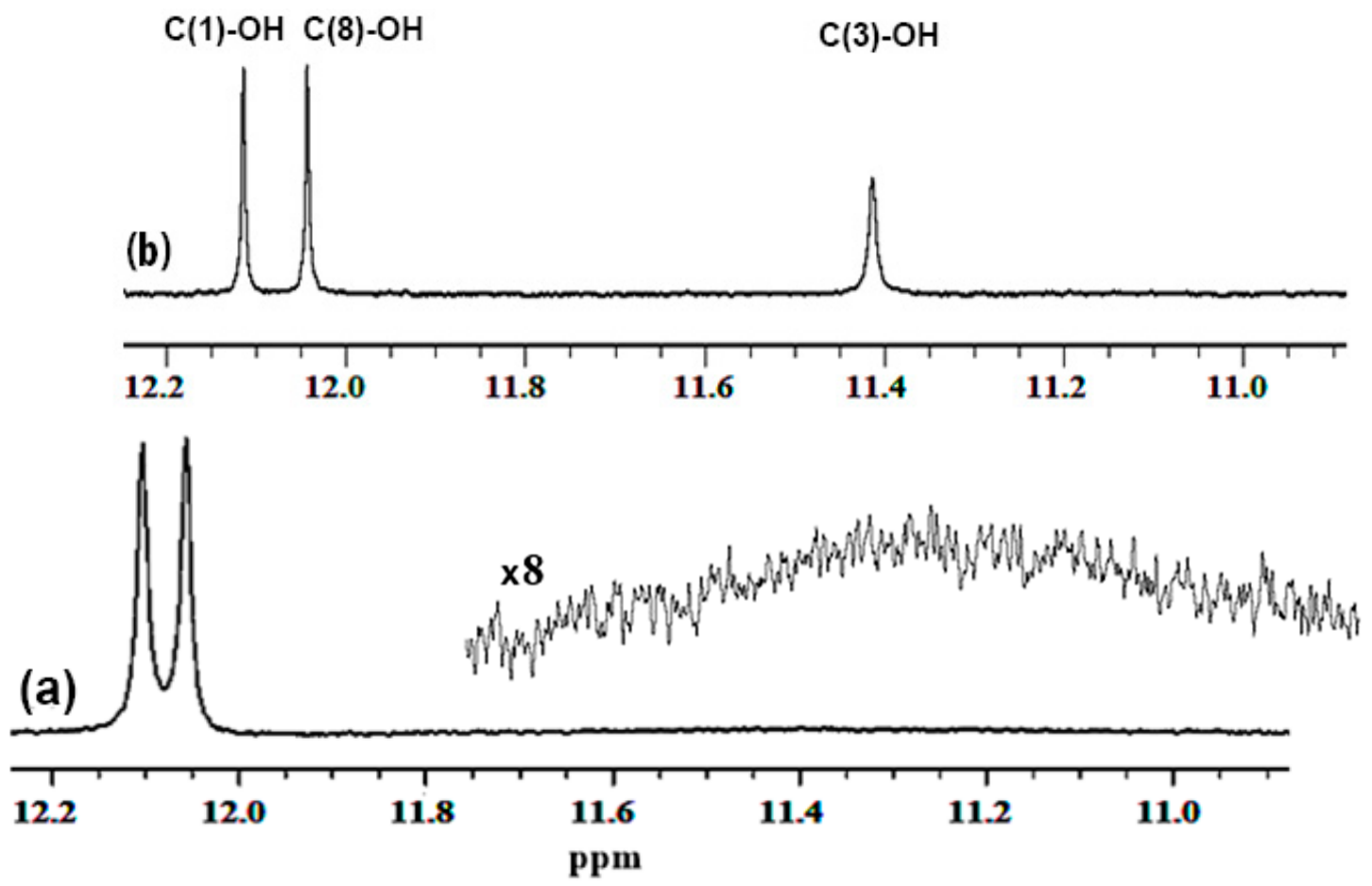

Figure 1. $\mathrm{OH}^{1} \mathrm{H}-\mathrm{NMR}$ spectral region $\left(400 \mathrm{MHz}\right.$ ) of emodin (2) in DMSO- $\mathrm{d}_{6}$ before addition (a) and after the addition of $2 \mu \mathrm{L}$ of TFA (b).

Surprisingly, a deuterium isotopic effect was observed, when the spectra were recorded in acetone- $\mathrm{d}_{6}$. Figure 2a shows a splitting of the peaks of the $\mathrm{C}(1)-\mathrm{OH}$ and $\mathrm{C}(8)-\mathrm{OH}$ groups which is attributed to the high content of residual $\mathrm{D}_{2} \mathrm{O}$ in the acetone- $\mathrm{d}_{6}$ solvent. In cases that the $\mathrm{OH}\left({ }^{2} \mathrm{H}\right)$ exchange rate is slow in the NMR time scale, two separate resonances are observed due to the proton and deuterium species, with relative intensities which depend on the $\mathrm{H} /{ }^{2} \mathrm{H}$ fractionation ratio [36,49]. Several long range ${ }^{n} \Delta \mathrm{H}\left({ }^{2} \mathrm{H}\right)$ isotope effects have been reported in the literature and their magnitude is larger in cases of strong intramolecular hydrogen bond [43,50]. Figure $2 \mathrm{~b}$ shows that, after the addition of $1-2 \mu \mathrm{L}$ of $\mathrm{H}_{2} \mathrm{O}$, the more deshielded resonances of the doublets were reduced significantly in intensity because of the substitution of ${ }^{2} \mathrm{H}$ with the ${ }^{1} \mathrm{H}$ isotope. This furthermore revealed that the long-range deuterium isotopic effect, $\Delta \mathrm{H}\left({ }^{2} \mathrm{H}\right)=\delta_{\mathrm{H}}-\delta_{\mathrm{H} /}{ }^{2} \mathrm{H}$, which is transmitted through the intramolecular hydrogen bond (Figure 2), is negative and the magnitude was found to be: chrysophanol $\mathrm{C}(1)-\mathrm{OH}\left({ }^{2} \mathrm{H}\right) \approx-14.0 \mathrm{ppb}$ and $\mathrm{C}(8)-\mathrm{OH}\left({ }^{2} \mathrm{H}\right)$ $\approx-14.0 \mathrm{ppb} ;$ emodin $\mathrm{C}(1)-\mathrm{OH}\left({ }^{2} \mathrm{H}\right) \approx-18.5 \mathrm{ppb}$ and $\mathrm{C}(8)-\mathrm{OH}\left({ }^{2} \mathrm{H}\right) \approx-19.6 \mathrm{ppb}$ and physcion $\mathrm{C}(1)-\mathrm{OH}\left({ }^{2} \mathrm{H}\right)$ $\approx-19.4 \mathrm{ppb}$ and $\mathrm{C}(8)-\mathrm{OH}\left({ }^{2} \mathrm{H}\right) \approx-18.0 \mathrm{ppb}$, where ppb denotes parts-per-billion, $10^{-9}$. 

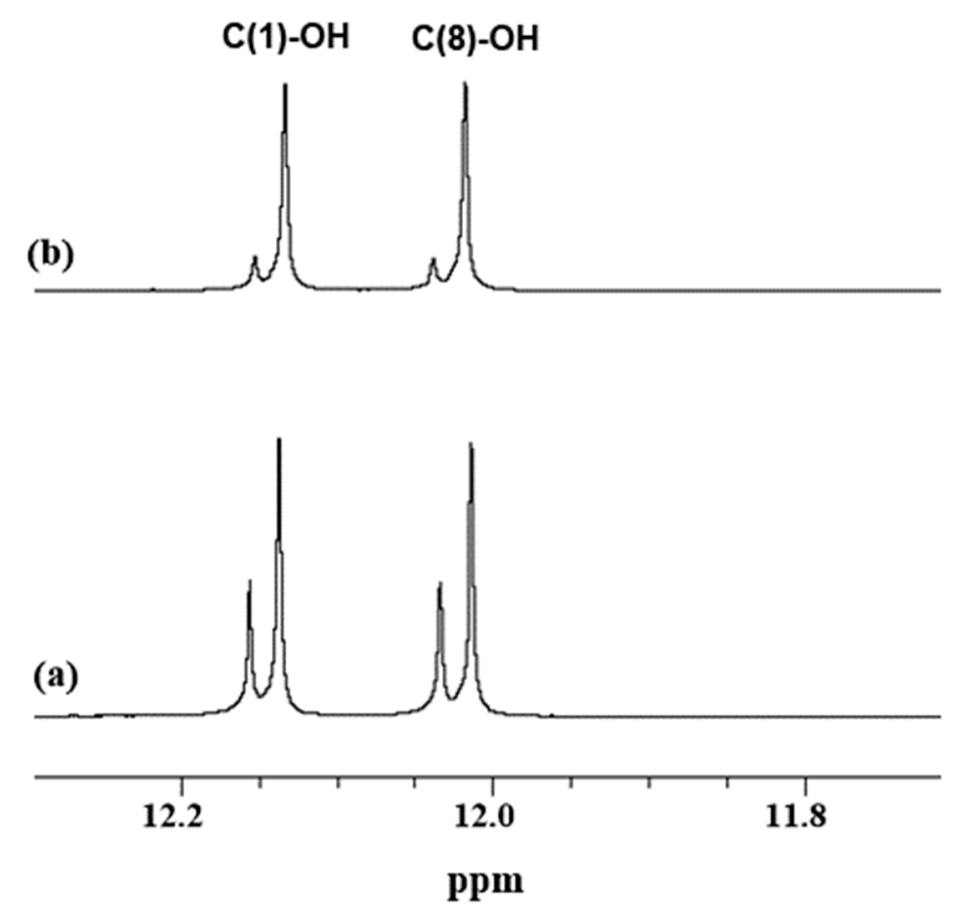

Figure 2. (a) The long range deuterium isotopic effect on the $\mathrm{C}(1)-\mathrm{OH}$ and $\mathrm{C}(8)-\mathrm{OH}$ groups of emodin, (2) in acetone- $\mathrm{d}_{6}(400 \mathrm{MHz})$. (b) Addition of $0.5 \mu \mathrm{L}$ of $\mathrm{H}_{2} \mathrm{O}$ reveals a negative ${ }^{2} \mathrm{H}$ isotope effect.

\subsubsection{Temperature-Dependence of ${ }^{1} \mathrm{H}-\mathrm{NMR}$ Chemical Shifts}

The temperature coefficient of the chemical shifts of $\mathrm{OH}$ groups, $\Delta \delta / \Delta \mathrm{T}$, can provide useful information to distinguish intra- and inter- molecular hydrogen bond which is complimentary to that obtained with the use of solvent effects [10,11,40-42]. Figure S2 shows variation in the chemical shift of $\mathrm{C}(1)-\mathrm{OH}, \mathrm{C}(8)-\mathrm{OH}$ and $\mathrm{C}(3)-\mathrm{OH}$ of emodin (2) in $\mathrm{CDCl}_{3}$, acetone- $\mathrm{d}_{6}$ and DMSO- $\mathrm{d}_{6}$ at different temperatures. The $\mathrm{OH}$ resonances are shielded linearly as the temperature increases and this results in negative temperature coefficients with the coefficient of determination $R^{2}>0.997$. In all cases, the $\Delta \delta / \Delta T$ values of $\mathrm{C}(1)-\mathrm{OH}$ and $\mathrm{C}(8)-\mathrm{OH}$ were found to be very small and in the range of -0.4 to $-2.1 \mathrm{ppb} / \mathrm{K}$ (Table 2) which demonstrate that these groups are involved in a strong intramolecular hydrogen bond with the $C(9)=O$ carbonyl oxygen. These results are in excellent agreement with the very small variation of chemical shifts in various solvents which were found to be $|\Delta \delta|<0.15 \mathrm{ppm}$ (Table 1 ). $\Delta \delta / \Delta \mathrm{T}$ values of the $\mathrm{C}(3)-\mathrm{OH}$ group of emodin (2) are in the range of -5.3 to $-19.1 \mathrm{ppb} / \mathrm{K}$ (Table 2). Surprisingly, the $\Delta \delta / \Delta \mathrm{T}$ value in $\mathrm{CDCl}_{3}(-19.1 \mathrm{ppb} / \mathrm{K})$ is significantly larger than those in DMSO- $\mathrm{d}_{6}$ and acetone- $\mathrm{d}_{6}$, although $\mathrm{CDCl}_{3}$ is a weak hydrogen bond donor solvent. This indicates that the $\mathrm{C}(3)-\mathrm{OH}$ group is involved in strong solute-to-solute intermolecular hydrogen bond interaction although the solution concentration was $<2 \mathrm{mM}$. This is in agreement with literature data on large temperature coefficients of $\mathrm{NH}$ chemical shifts in $\mathrm{CDCl}_{3}$ when intermolecular self-association is significant [51]. Interestingly, the line width of the $\mathrm{C}(3)-\mathrm{OH}$ resonance in $\mathrm{CDCl}_{3}$ decreases by increasing the temperature, contrary to the case in acetone- $\mathrm{d}_{6}$ and DMSO- $\mathrm{d}_{6}$ (Supplementary materials, Figure S2). This implies that the mechanism of proton transfer in $\mathrm{CDCl}_{3}$ involves intermolecular solute-to-solute hydrogen bond which is broken by increasing the temperature. On the contrary, in acetone- $\mathrm{d}_{6}$ and DMSO- $\mathrm{d}_{6}$ the proton transfer involves the phenol-OH group and traces of water in the organic solution and, thus, the exchange rate increases by increasing the temperature. 
Table 2. Chemical shift temperature coefficients, $\Delta \delta / \Delta \mathrm{T}$, of hydroxyl protons of chrysophanol (1), emodin (2), and physcion (3), in $\mathrm{CDCl}_{3}$, acetone- $\mathrm{d}_{6}$ and DMSO- $\mathrm{d}_{6}$.

\begin{tabular}{ccccc}
\hline \multirow{2}{*}{ Compound } & \multirow{2}{*}{ Group } & \multicolumn{3}{c}{$\Delta \delta / \Delta \mathbf{T}^{\mathbf{a}}$} \\
\cline { 3 - 5 } & & $\mathbf{C D C l}_{\mathbf{3}}$ & Acetone-d $_{\mathbf{6}}$ & DMSO-d $_{\mathbf{6}}$ \\
\hline Chrysophanol (1) & $\mathrm{C}(1)-\mathrm{OH}$ & -1.9 & -1.1 & -1.8 \\
& $\mathrm{C}(8)-\mathrm{OH}$ & -1.8 & -1.1 & -0.4 \\
Emodin (2) & $\mathrm{C}(1)-\mathrm{OH}$ & -1.7 & -1.2 & -1.1 \\
& $\mathrm{C}(8)-\mathrm{OH}$ & -2.1 & -1.2 & -0.7 \\
\multirow{2}{*}{ Physcion (3) } & $\mathrm{C}(3)-\mathrm{OH}$ & -19.1 & -9.7 & -5.3 \\
& $\mathrm{C}(1)-\mathrm{OH}$ & -1.9 & -1.1 & -1.9 \\
& $\mathrm{C}(8)-\mathrm{OH}$ & -1.8 & -1.0 & -0.6 \\
\hline
\end{tabular}

${ }^{\mathrm{a}}$ Expressed, relative to the solvent resonance, in parts-per-billion, $10^{-9}(\mathrm{ppb})$ per K.

\subsection{Quantum Chemical Calculations}

2.2.1. DFT-Calculated vs. Experimental ${ }^{1} \mathrm{H}-\mathrm{NMR}$ Chemical Shifts in Solution with CPCM: Effects of Various Functionals and Basis Sets

Table S2 illustrates DFT-calculated [52] ${ }^{1} \mathrm{H}$ NMR chemical shifts $\left(\delta_{\text {calc }}\right)$ of chrysophanol $(\mathbf{1})$, emodin (2), and physcion (3), with optimization of the structures at the B3LYP/6-31+G(d), wB97XD/6-31+G(d), APFD/6-31+G(d), M06-2X/Def2TZVP, and TPSSh/TZVP level of theory, with CPCM [53] in $\mathrm{CHCl}_{3}$, acetone, and DMSO. The presence of various conformers of the $\mathrm{C}(3)-\mathrm{OH}$ and $\mathrm{C}(3)-\mathrm{OCH}_{3}$ substituents in emodin (2) and physcion (3) complicates the interpretation of the computed chemical shifts (see discussion below), therefore, chrysophanol (1) was selected to investigate the effect of the basis set on the optimized geometries and the quality of the ${ }^{1} \mathrm{H}-\mathrm{NMR}$ chemical shift calculations.

Figure 3 illustrates calculated ${ }^{1} \mathrm{H}-\mathrm{NMR}$ chemical shifts (at the GIAO/B3LYP/6-311+G(2d,p) level with $\mathrm{CPCM}$ in $\mathrm{CHCl}_{3}$ ) vs. experimental ${ }^{1} \mathrm{H}-\mathrm{NMR}$ chemical shifts of chrysophanol (1), with optimization of the structures using the above five functionals and the three basis sets. Very good linear regression correlation coefficients and standard deviations of the ${ }^{1} \mathrm{H}-\mathrm{NMR}$ chemical shifts were obtained for the various functionals and basis sets used (Table 3). Interestingly, calculations at the B3LYP/6-31+G(d) level performed better in terms of mean square error and slope than that at the TPSSh/TZVP level. It can, therefore, be concluded that accurate results may not require computationally demanding basis sets in order to obtain optimized geometries. This is in excellent agreement with the conclusion of a recent comprehensive review article that increasing basis set and computational time does not necessarily result in more accurate chemical shifts at least with B3LYP [20].

Table 3. Linear regression correlation coefficient, mean square error and slope of calculated vs. experimental ${ }^{1} \mathrm{H}-\mathrm{NMR}$ chemical shifts of chrysophanol (1), determined from various optimised geometries with CPCM in $\mathrm{CHCl}_{3}$.

\begin{tabular}{cccc}
\hline Method & Correlation Coefficient $\left(\mathbf{R}^{\mathbf{2}}\right)$ & Mean Square Error & Slope \\
\hline B3LYP/6-31+G(d) & 0.9995 & 0.0082 & 1.0303 \\
$\omega B$ 97XD/6-31+G(d) & 0.9962 & 0.0573 & 0.9953 \\
APFD/6-31+G(d) & 0.9997 & 0.0046 & 1.0498 \\
M06-2X/Def2TZVP & 0.9961 & 0.0592 & 0.9934 \\
TPSSh/TZVP & 0.9981 & 0.0352 & 1.0915 \\
\hline
\end{tabular}

An intramolecular hydrogen bond of the $\mathrm{C}(1)-\mathrm{OH}$ and $\mathrm{C}(8)-\mathrm{OH}$ groups with the carbonyl $\mathrm{CO}$ oxygen was observed in the DFT calculated structures of chrysophanol (1), emodin (2), and physcion (3) in the three solvents studied. The computed ${ }^{1} \mathrm{H}-\mathrm{NMR}$ chemical shifts of the $\mathrm{C}(1)-\mathrm{OH}$ and $\mathrm{C}(8)-\mathrm{OH}$ groups were found in the range of $811-12$ in $\mathrm{CHCl}_{3}$, acetone, and in DMSO and in very good agreement with the experimental ${ }^{1} \mathrm{H}-\mathrm{NMR}$ chemical shifts (Supplementary materials, Table S2). This demonstrates 
that the intramolecular hydrogen bond is independent of the solvents used. On the contrary, the solvent-dependent experimental ${ }^{1} \mathrm{H}-\mathrm{NMR}$ chemical shifts of the $\mathrm{C}(3)-\mathrm{OH}$ group of emodin (2) strongly deviate from the computational data: $\delta_{\text {exp,acetone }}-\delta_{\text {calc,acetone }}=4.82 \mathrm{ppm}$ and $\delta_{\text {exp,DMSO }}-\delta_{\text {calc,DMSO }}=$ $6.01 \mathrm{ppm}$. This indicates that the continuum model is not appropriate for solvent exposed OH groups and, thus, it is necessary the incorporation of discrete molecules of solvent (discussed in Section 2.2.3).

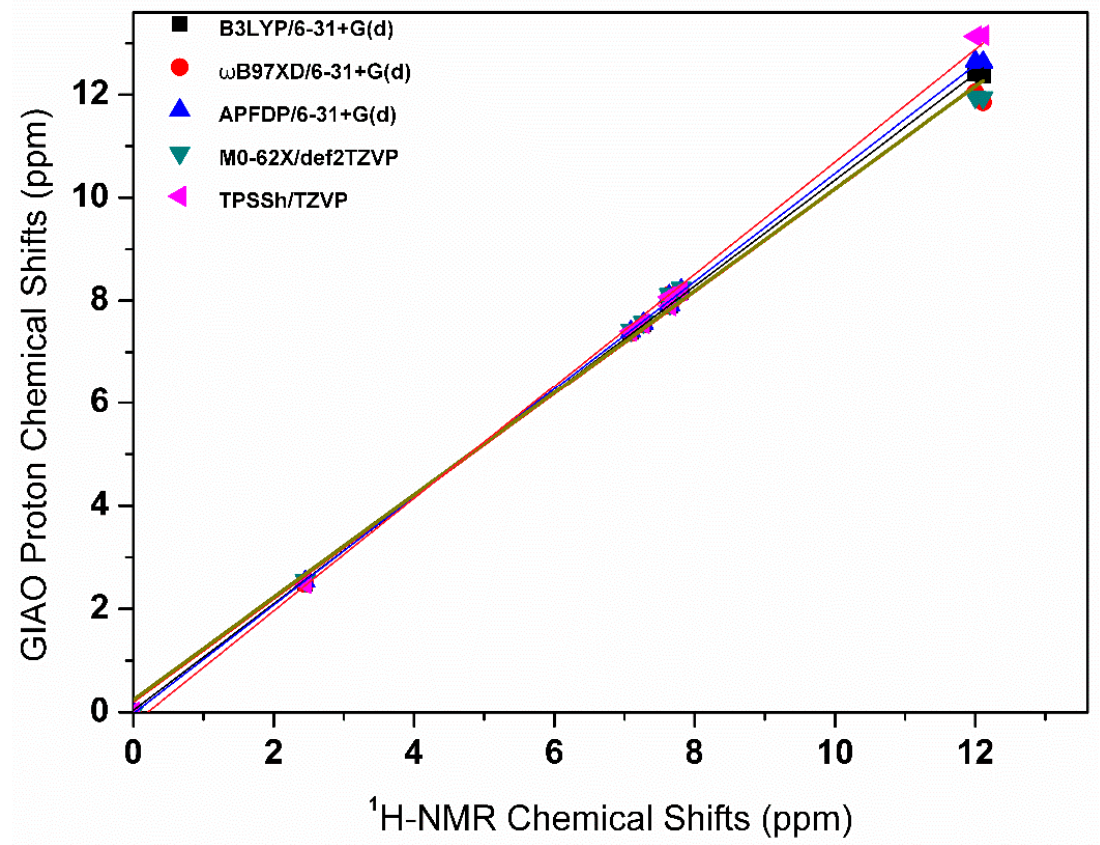

Figure 3. Calculated ${ }^{1} \mathrm{H}-\mathrm{NMR}$ chemical shifts (at the GIAO/B3LYP/6-311+G(2d,p) level with CPCM in $\mathrm{CHCl}_{3}$ ) vs. experimental ${ }^{1} \mathrm{H}-\mathrm{NMR}$ chemical shifts of chrysophanol (1), with optimization of the structures using various functionals and basis sets.

\subsubsection{Effect of Conformation of Substituents on the Calculated ${ }^{1} \mathrm{H}-\mathrm{NMR}$ Chemical Shifts}

The effect of the $\mathrm{C}(3)-\mathrm{OH}$ and $\mathrm{C}(3)-\mathrm{OCH}_{3}$ substituents of emodin (2) and physcion (3), on the calculated ${ }^{1} \mathrm{H}-\mathrm{NMR}$ chemical shifts, has been investigated in detail. Figure 4 illustrates the electronic energy (Hartree units) of emodin (2) as a function of the torsion angle $\varphi=\mathrm{C}(4)-\mathrm{C}(3)-\mathrm{O}(3)-\mathrm{H}(3)$, at the B3LYP/6-31 + G(d) level (gas phase). As expected, a maximum of the electronic energy for a torsion angle $\varphi=90^{\circ}$ was observed. The Gibbs energy of conformer $\mathrm{A}\left(\varphi=0^{\circ}\right)$ was found to be lower by $0.24 \mathrm{kcal} / \mathrm{mol}$ with respect to that with $\varphi=180^{\circ}$. Similar results were obtained with the various functionals and basis sets of Table S3. This implies that there is an equilibrium of the two fast-interconverting, on the NMR time scale, conformers with nearly equal populations. Although the energy difference of the two conformers of emodin (2) is negligible $(\Delta \mathrm{G}=0.24$ to $0.11 \mathrm{kcal} / \mathrm{mol})$, their dipole moments differ significantly, due to the different orientation of the hydroxyl group $\left(\mu_{A}=2.8 \mathrm{D}\right.$ and $\left.\mu_{B}=0.4 \mathrm{D}\right)$ (Supplementary materials, Figure S3).

Figure 5 illustrates the dependence of calculated GIAO ${ }^{1} \mathrm{H}-\mathrm{NMR}$ chemical shifts of emodin (2) as a function of torsion angle $\varphi$. A broad minimum of the computed $\delta\left({ }^{1} \mathrm{H}\right) \mathrm{NMR}$ chemical shifts of the $\mathrm{OH}$ group was observed for $\varphi=90^{\circ}$ with a maximum shielding of $\sim 1.8$ ppm than in the in-plane conformers. The $\mathrm{H}(2)$ and $\mathrm{H}(4)$ protons, which are in ortho position with respect to the $\mathrm{OH}$ group, demonstrate a Karplus-like variation with a deshielding of $\sim 0.4 \mathrm{ppm}$ for $\varphi=90^{\circ}$. The chemical shift difference of the $\mathrm{H}(2)$ and $\mathrm{H}(4)$ protons for $\varphi=0^{\circ}$ is $0.5 \mathrm{ppm}$ and increases up to $0.95 \mathrm{ppm}$ for $\varphi=180^{\circ}$. Of particular interest is the dependence of calculated chemical shifts of the $\mathrm{C}(1)-\mathrm{OH}$ and $\mathrm{C}(8)-\mathrm{OH}$ groups as a function of the $\varphi$ angle. For $\varphi=0^{\circ}$, the $\mathrm{C}(1)-\mathrm{OH}$ proton is more shielded than the $\mathrm{C}(8)-\mathrm{OH}$ while for $\varphi=180^{\circ}$ is more deshielded with a significant increase in the chemical shift difference of $\mathrm{C}(1)-\mathrm{OH}$ and $\mathrm{C}(8)-\mathrm{OH}$, which can provide a criterion of the conformation of the $\mathrm{OH}$ substituent. 


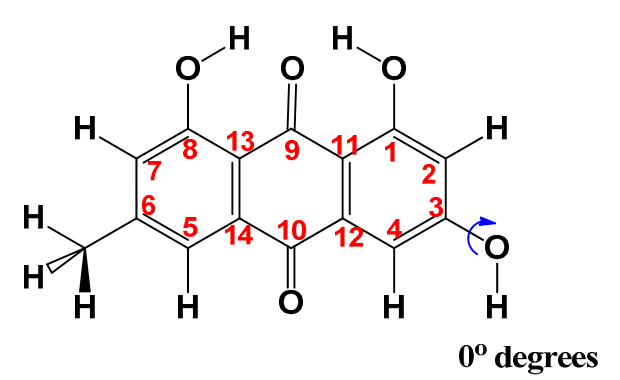

conformer A<smiles></smiles>

$180^{\circ}$ degrees

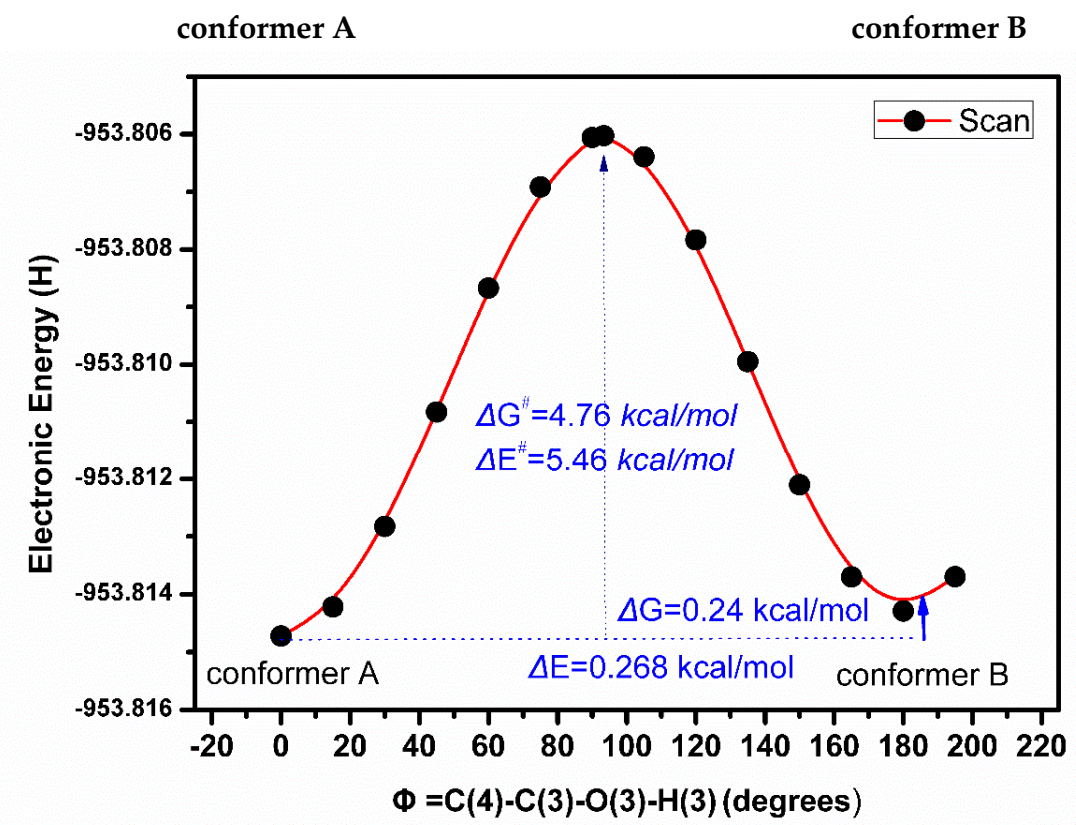

Figure 4. Electronic energy (Hartree unit) of emodin (2), as a function of the torsion angle $\varphi$ : $\mathrm{C}(4)-\mathrm{C}(3)-\mathrm{O}(3)-\mathrm{H}(3)$. All calculations were carried out, in steps of $15^{\circ}$, at the B3LYP/6-31 + G(d) level (gas phase) and the NMR calculations with GIAO at the B3LYP/6-311G + $(2 \mathrm{~d}, \mathrm{p})$ level with continuum $\left(\mathrm{CPCM}-\mathrm{CHCl}_{3}\right)$.

Figure 6 shows one of the molecular orbitals for conformer A of emodin (2). It can be seen clearly that there exists a bonding lobe embracing atoms $\mathrm{H}(3), \mathrm{O}(3), \mathrm{C}(3), \mathrm{C}(2), \mathrm{C}(1), \mathrm{O}(1)$, and the hydrogen atom $\mathrm{H}(1)$ which participates in the intramolecular hydrogen bond. This affects the electron density at the hydrogen atom and, consequently, the corresponding chemical shift. Molecular orbital having similar bonding characteristics could not be found for conformer B. The intramolecular hydrogen bond distances for conformer A are almost identical $(\mathrm{O}(1)-\mathrm{H}(1) \cdots \mathrm{O}(9)=1.703 \AA$ and $\mathrm{O}(8)-\mathrm{H}(8) \cdots \mathrm{O}(9)$ $=1.704 \AA)$, while for conformer $\mathrm{B}$ there is a significant difference $(\mathrm{O}(1)-\mathrm{H}(1) \cdots \mathrm{O}(9)=1.695 \AA$ and $\mathrm{O}(8)-\mathrm{H}(8) \cdots \mathrm{O}(9)=1.704 \AA)$. The shortest hydrogen bond distance of $\mathrm{H}(1)$ in conformer $\mathrm{B}$ is also reflected in the deshielding with respect to $\mathrm{H}(8)$ which can be interpreted taking into consideration the well-established linear relationship of $\delta\left({ }^{1} \mathrm{H}\right)$ vs. $(\mathrm{O}) \mathrm{H} \cdots \mathrm{O}$ distances $[8,9,26,29]$.

Figure 7 illustrates the electronic energy (Hartree unit) of physcion (3) as a function of the torsion angle $\varphi=\mathrm{C}(4)-\mathrm{C}(3)-\mathrm{O}(3)-\mathrm{C}\left(3^{\prime}\right)$ of the $\mathrm{OCH}_{3}$ group. Contrary to the case of emodin, the Gibbs energy of conformer A $\left(\varphi=0^{\circ}\right)$ was found to be higher by $\sim 0.07 \mathrm{kcal} / \mathrm{mol}$ than that with $\varphi=180^{\circ}$. The maximum deshielding of the $\mathrm{C}(4)-\mathrm{H}$ and $\mathrm{C}(2)-\mathrm{H}$ occurs at $\varphi=60^{\circ}$ and $120^{\circ}$, respectively. Of particular interest is the complex dependence of calculated chemical shifts of the $\mathrm{C}(1)-\mathrm{OH}$ and $\mathrm{C}(8)-\mathrm{OH}$ protons as a function of torsion angle $\varphi$ (Supplementary materials, Figure S4). In the case of $\varphi<30^{\circ}$, the $\mathrm{C}(1)-\mathrm{OH}$ proton is more deshielded than the $\mathrm{C}(8)-\mathrm{OH}$, and for $\varphi>30^{\circ}$ becomes more deshielded with a maximum chemical shift difference of $\sim 0.45 \mathrm{ppm}$ for $\varphi=180^{\circ}$. This difference, therefore, can be used as a criterion of the conformation of the $\mathrm{OCH}_{3}$ substituent. 


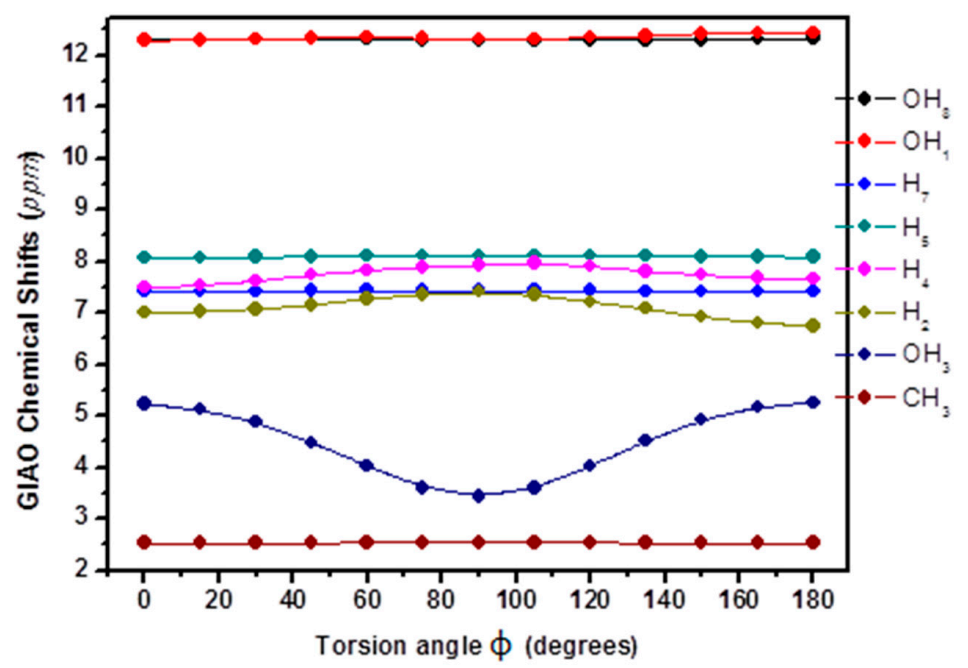

(A)

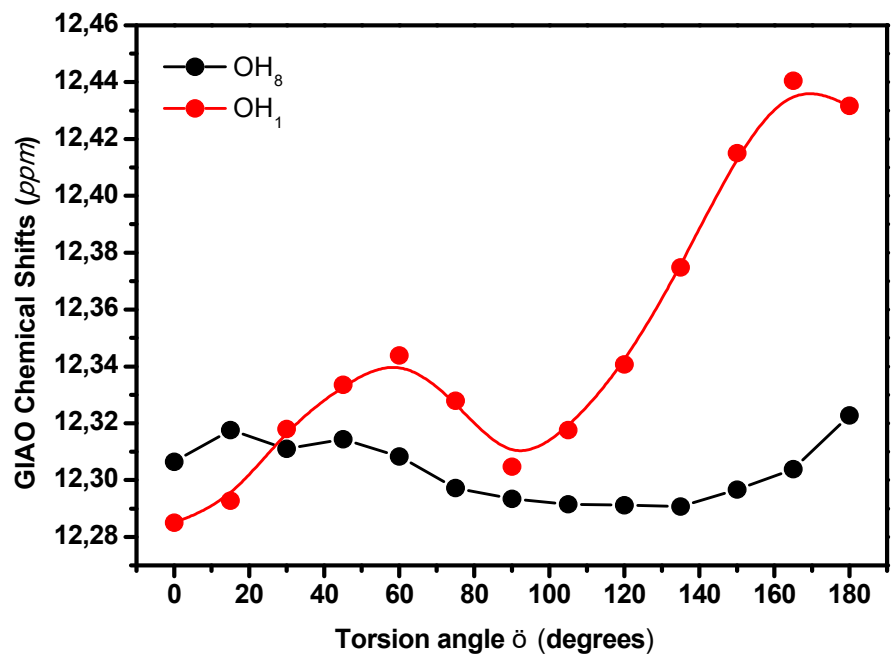

(B)

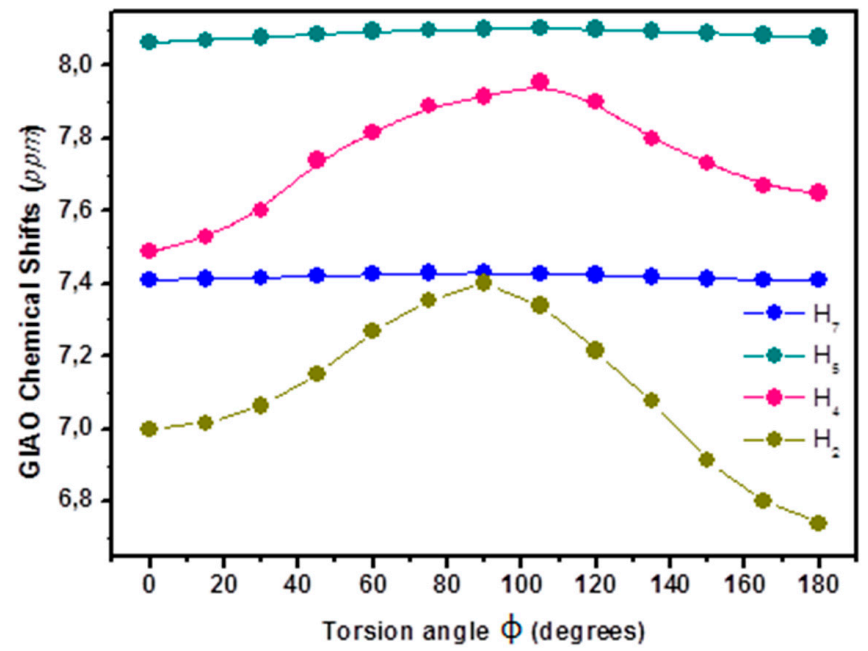

(C)

Figure 5. Dependence of calculated, $\delta_{\text {calc }}$, GIAO ${ }^{1} \mathrm{H}-\mathrm{NMR}$ chemical shifts of emodin (2) as a function of the torsion angle $\varphi=\mathrm{C}(4)-\mathrm{C}(3)-\mathrm{O}(3)-\mathrm{H}(3)$ in steps of $15^{\circ}$. 


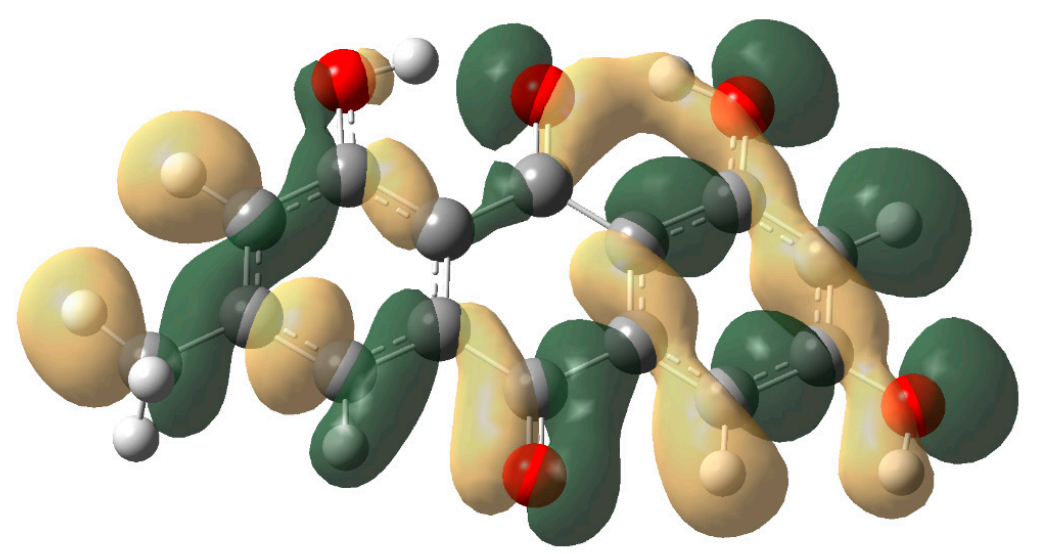

Figure 6. Molecular orbital for conformer A of emodin (2) embracing atoms $\mathrm{H}(3), \mathrm{O}(3), \mathrm{C}(3), \mathrm{C}(2), \mathrm{C}(1)$, $\mathrm{O}(1)$ and hydrogen atom $\mathrm{H}(1)$ which participates in the intramolecular hydrogen bond $(\mathrm{C}=\mathrm{O} \cdots \mathrm{H}-\mathrm{O})$.

Figure 8 illustrates molecular orbital analysis of conformers A and B of physcion (3). Although the energy difference between the two conformers is negligible $(\Delta \mathrm{E}=0.23 \mathrm{kcal} / \mathrm{mol}, \Delta \mathrm{G}=0.07 \mathrm{kcal} / \mathrm{mol})$, the rotation of the methoxy group $\left(-\mathrm{OCH}_{3}\right)$ affects differently the electron density at the hydrogen atom which is involved in the intramolecular hydrogen bond. The effect for conformer $B$ is transmitted through a sigma $(\sigma)$ bonding molecular orbital (MO) embracing all the atoms $\mathrm{O}(3), \mathrm{C}(3), \mathrm{C}(2), \mathrm{C}(1)$, $\mathrm{O}(1), \mathrm{H}(1)$, and $\mathrm{O}(9)$, while for conformer $\mathrm{A}$ an antibonding region between $\mathrm{O}(3)$ and $\mathrm{C}(3)$ is evident.<smiles>COc1cccc(OC)c1C=O</smiles>

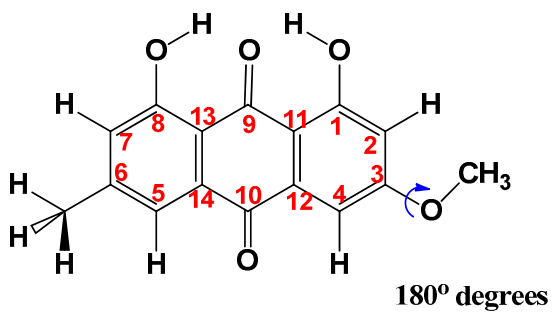

conformer B

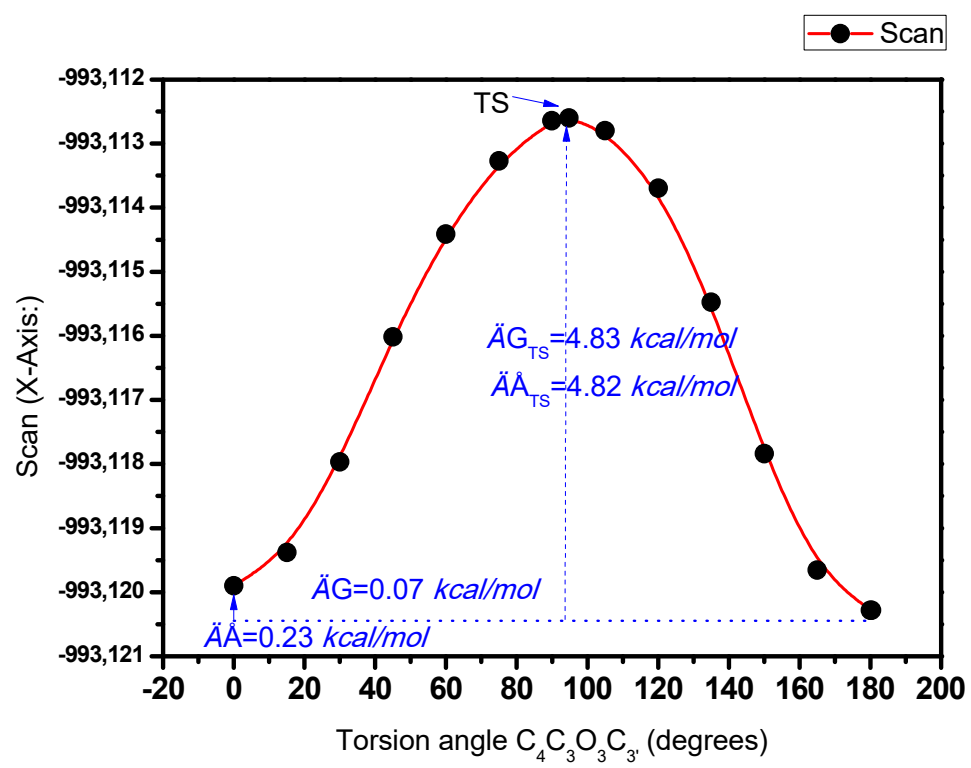

Figure 7. Electronic energy (Hartree unit) of physcion (3) as a function of the torsion angle $\varphi$ : $\mathrm{C}(4)-\mathrm{C}(3)-\mathrm{O}(3)-\mathrm{C}\left(3^{\prime}\right)$. All calculations were carried out, in steps of $15^{\circ}$, at the B3LYP/6-31 + G(d) level (gas phase) and the NMR calculations with GIAO at the B3LYP/6-311G+(2d,p) level with continuum $\left(\mathrm{CPCM}-\mathrm{CHCl}_{3}\right)$. 


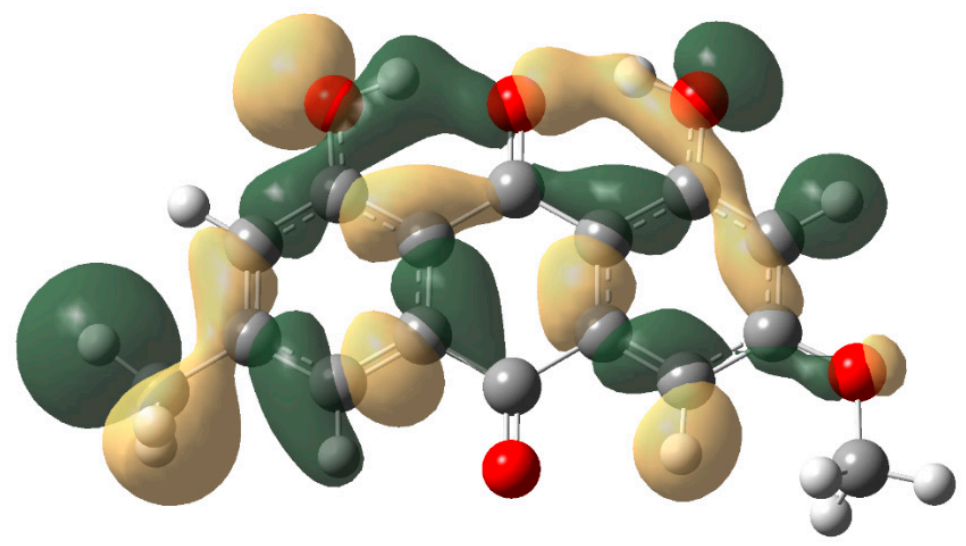

Conformer A

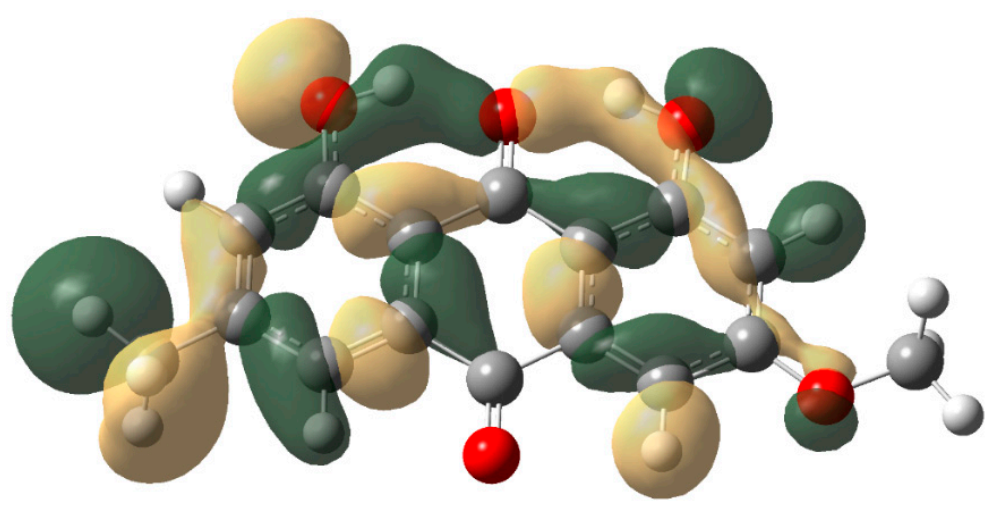

Conformer B

Figure 8. Molecular orbitals of conformers A and B of physcion (3).

Due to rotation of the methyl group substituent in chrysophanol (1), emodin (2), and physcion (3), the minimum Gibbs energy conformational state is the one in which the $\mathrm{C}-\mathrm{H}$ group is in the eclipsed conformation with respect to the planar aromatic system (Supplementary materials, Figure S5).

2.2.3. Effect of Discrete Solvent Molecules on Intra- and Intermolecular Hydrogen Bond Interactions and Conformation of Substituents

As pointed out in Section 2.2.1, the continuum model is not appropriate for solvent-exposed $\mathrm{OH}$ groups, therefore, the effect of discrete solvation molecules was investigated in detail. For emodin (2) with one molecule of chloroform, optimized in continuum ( $\left.\mathrm{CPCM}-\mathrm{CHCl}_{3}\right)$, two conformers ( $\mathrm{A}$ and B, Supplementary materials, Figure S6) which constitute minima on the potential energy surface (PES), were obtained with their energy difference being only $0.04 \mathrm{kcal} / \mathrm{mol}$ (Supplementary materials, Table S4). A typical hydrogen bond was observed between the lone electron pair of the phenolic oxygen and the hydrogen of the chloroform with $\mathrm{H}$... O distances of $2.223 \AA$ and $2.227 \AA$ for conformers $\mathrm{A}$ and $\mathrm{B}$, respectively. These values can be compared with a distance of $2.175 \AA$ obtained for a 1:1 $\mathrm{PhOH}+\mathrm{CHCl}_{3}$ complex [41]. Molecular orbital analysis for the two conformers A and B (Supplementary materials, Figure S7) shows that the rotation of the $\mathrm{C}(3)-\mathrm{OH}$ hydroxyl group, which forms an intermolecular hydrogen bond with the chloroform molecule, will influence the chemical shift of proton $\mathrm{C}(1)-\mathrm{OH}$. For conformer $\mathrm{A}$, this effect will be greater than the corresponding conformer $\mathrm{B}$, since in the former case a bonding lobe embracing atoms, $\mathrm{H}(3), \mathrm{O}(3), \mathrm{C}(3), \mathrm{C}(2), \mathrm{C}(1), \mathrm{O}(1), \mathrm{H}(1), \mathrm{O}(9)$, and $\mathrm{C}(9)$ is clearly seen, while for conformer $\mathrm{B}$ the corresponding lobe has an antibonding character. Consequently, the electron density at $\mathrm{H}(4)$ will be different in the two conformers and, hence, their chemical shifts. 
The optimized-structures of conformers A and B of emodin (2) in continuum (CPCM-DMSO) with a single molecule of DMSO at the $\mathrm{C}(3)-\mathrm{OH}$ group are shown in Figure 9. Conformer A exists in two local minima $A_{1}$ and $A_{2}$ with an energy difference of only $0.08 \mathrm{kcal} / \mathrm{mol}(\Delta \mathrm{G} \sim 0.04 \mathrm{kcal} / \mathrm{mol})$. Both conformers $\mathrm{A}_{1}$ and $\mathrm{A}_{2}$ are more stable than conformer $\mathrm{B}$ (Supplementary materials, Table S4). The stabilization of all conformers may be attributed to the strong intermolecular hydrogen bonds $\mathrm{O}-\mathrm{H} \cdots \mathrm{O}(\mathrm{S})$ of $1.639 \AA$ (conformer $\mathrm{A}_{1}$ ), $1.653 \AA$ (conformer $\mathrm{A}_{2}$ ) and $1.650 \AA$ (conformer $\mathrm{B}$ ). The $\mathrm{C}(3)-\mathrm{O}-\mathrm{H}$... O torsion angles were found to be $83.52^{\circ}$ (conformer $\mathrm{A}_{1}$ ), $-0.22^{\circ}$ (conformer $\mathrm{A}_{2}$ ) and $20.04^{\circ}$ (conformer $\mathrm{B}$ ), while the two methyl groups of DMSO are nearly perpendicular and symmetrical to the planar aromatic system in conformers $\mathrm{A}_{1}$ and $\mathrm{B}$. The hydrogen bond angles $\mathrm{O}-\mathrm{H} \cdots \mathrm{O}(\mathrm{S})$ were found to be $179.26^{\circ}$ (conformer $\mathrm{A}_{1}$ ), $177.67^{\circ}$ (conformer $\mathrm{A}_{2}$ ) and $177.29^{\circ}$ (conformer $\mathrm{B}$ ) and, thus, deviate slightly from linearity. The torsion angles $\mathrm{O}-\mathrm{H} \cdots \mathrm{O}=\mathrm{S}$ were found to be $125.01^{\circ}$ (conformer $\mathrm{A}_{1}$ ), $169.37^{\circ}$ (conformer $\mathrm{A}_{2}$ ) and $178.14^{\circ}$ (conformer B). Molecular orbital analysis demonstrates the existence of a bonding lobe embracing atoms $\mathrm{O}(3), \mathrm{C}(3), \mathrm{C}(2), \mathrm{C}(1), \mathrm{O}(1), \mathrm{H}(1), \mathrm{O}(9)$, and $\mathrm{C}(9)$ in conformer $\mathrm{A}_{2}$, while for conformers $\mathrm{A}_{1}$ and $\mathrm{B}$ the corresponding lobe has an antibonding character (Supplementary materials, Figure S8).
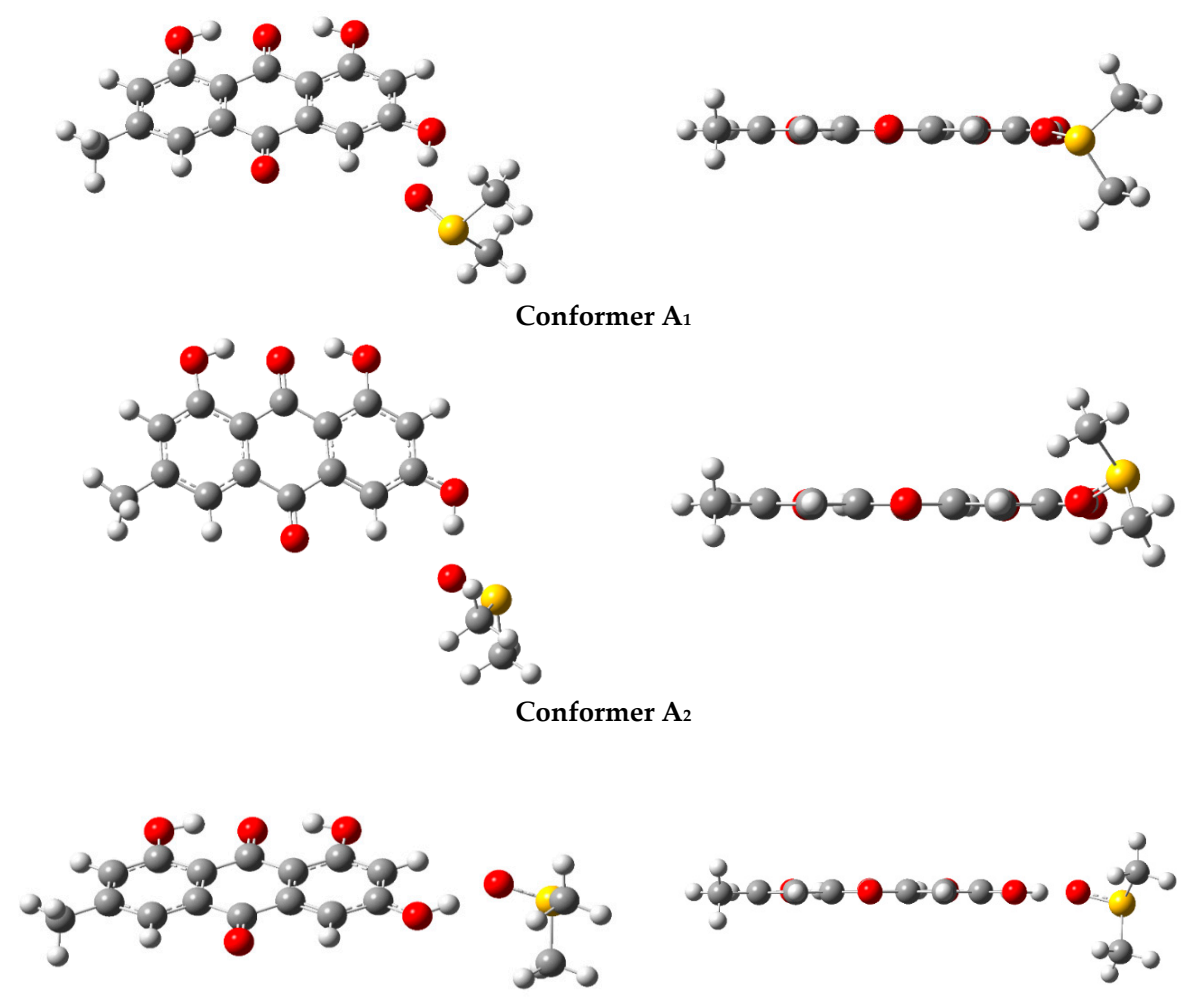

Conformer B

Figure 9. Different perspectives of the B3LYP/6-31 + G(d) (CPCM-DMSO) optimized structures of the three conformers $\mathrm{A}_{1}, \mathrm{~A}_{2}$, and $\mathrm{B}$ of emodin (2) with a discrete molecule of DMSO.

The optimized structures of conformers A and B of emodin (2) with a single molecule of acetone at the $\mathrm{C}(3)-\mathrm{OH}$ group are shown in Figure S9. The stabilization of both conformers may be attributed to a relatively strong intermolecular hydrogen bond $\mathrm{O}-\mathrm{H} \cdots \mathrm{O}(\mathrm{C})$ of $1.737 \AA$ and $1.735 \AA$ for conformers $\mathrm{A}$ and $\mathrm{B}$, respectively. The hydrogen bond angles $\mathrm{O}-\mathrm{H} \cdots \mathrm{O}(\mathrm{C})$ were found to be $175.26^{\circ}$ (conformer $\mathrm{A}$ ) and $175.88^{\circ}$ (conformer $\mathrm{B}$ ) and, thus, deviate slightly from linearity. The torsion angles $\mathrm{O}-\mathrm{H} \cdots \mathrm{O}=\mathrm{C}$ were found to be $110.46^{\circ}$ (conformer A) and $113.80^{\circ}$ (conformer B) and the torsion angles $\mathrm{C}-\mathrm{O}-\mathrm{H} \cdots \mathrm{O}(\mathrm{C}$ ) $139.09^{\circ}$ (conformer A) and $-134.7^{\circ}$ (conformer B).

Table S5 illustrates calculated $\left(\delta_{\text {calc }}, \mathrm{ppm}\right)$ and $\delta_{\exp }-\delta_{\text {calc }}{ }^{1} \mathrm{H}-\mathrm{NMR}$ chemical shifts of emodin (2) complexes with a single molecule of $\mathrm{DMSO}$, acetone, and $\mathrm{CHCl}_{3}$. The incorporation of discrete solvent molecule of DMSO and acetone induces a very significant variation in the chemical shift, due 
to intermolecular hydrogen bond of solvent molecule with the $\mathrm{C}(3)-\mathrm{OH}$ group of emodin (2). This results in excellent agreement of the computed, at the GIAO_B3LYP/6-311+G(2d,p) (CPCM-DMSO) level, with the experimental chemical shifts with $R^{2}=0.9991$ and 0.9992 , slopes of 1.0347 and 1.0305, and mean square errors of 0.0909 and $0.0882 \mathrm{ppm}$, for conformers $\mathrm{A}_{1}$ and $\mathrm{B}$, respectively (Figure 10a). Figure 10b illustrates calculated vs. experimental ${ }^{1} \mathrm{H}-\mathrm{NMR}$ chemical shifts of conformers A and $\mathrm{B}$ of emodin (2) in CPCM-DMSO. The results of the linear regression analysis $\left(R^{2}=0.7181\right.$ and 0.7822 , slopes of 0.8309 and 0.8384 and mean square errors of 1.5026 and $1.5057 \mathrm{ppm}$ for $\mathrm{A}$ and $\mathrm{B}$ conformers, respectively), clearly show a poor correlation mainly due to differences of the $\mathrm{C}(3)-\mathrm{OH}$ chemical shifts.
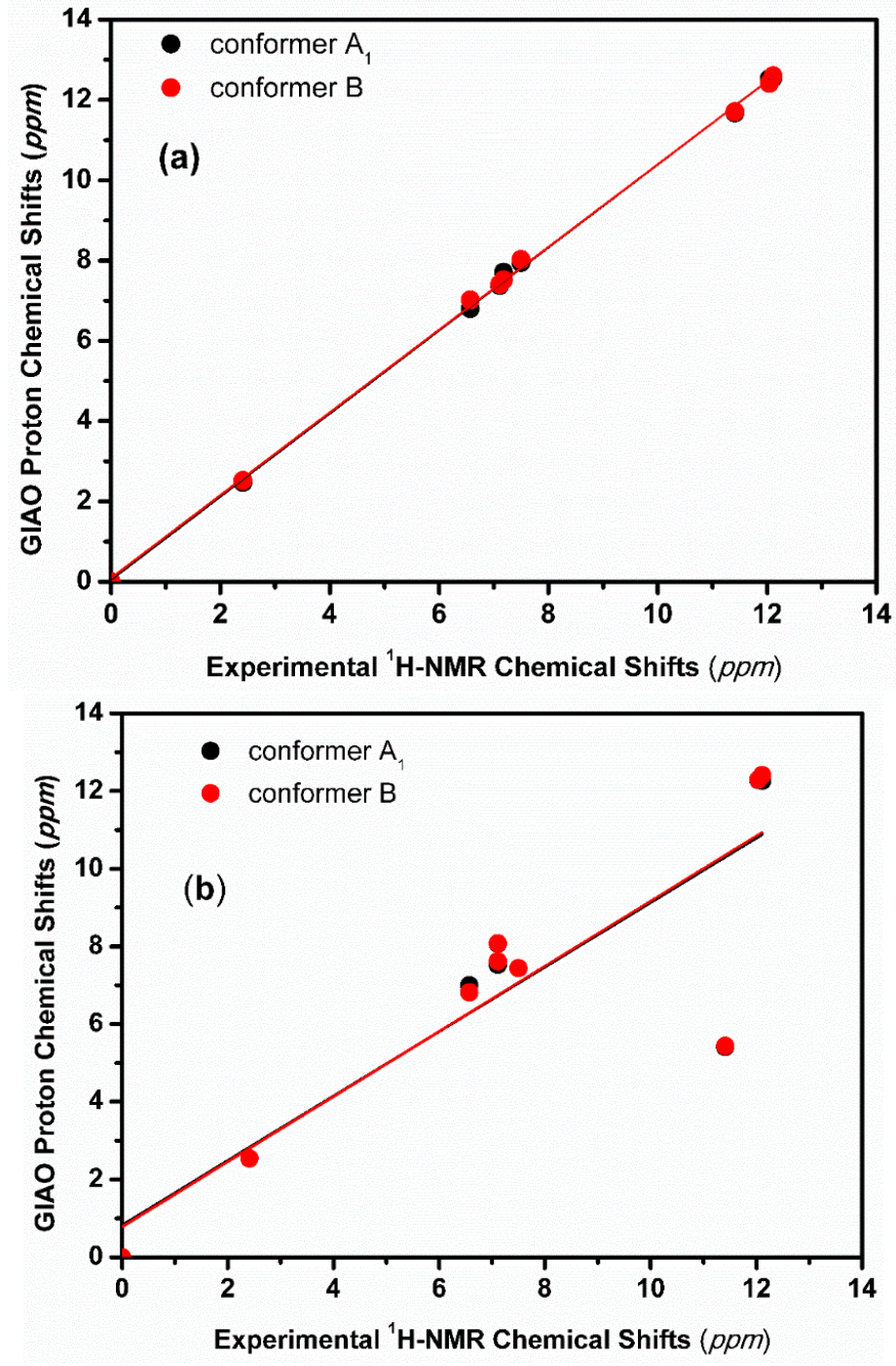

Figure 10. Calculated, at the GIAO_DFT/B3LYP/6-311+G(2d,p) level, vs. experimental ${ }^{1} \mathrm{H}-\mathrm{NMR}$ chemical shifts of conformers $\mathrm{A}_{1}$ and $\mathrm{B}$ of emodin (2): (a) with a discrete molecule of DMSO at the $\mathrm{C}(3)-\mathrm{OH}$ group in continuum (CPCM-DMSO) and (b) in continuum (CPCM-DMSO).

A discrete molecule of DMSO was also placed in the vicinity of either the $\mathrm{C}(1)-\mathrm{OH}$ or $\mathrm{C}(8)-\mathrm{OH}$ groups (Supplementary materials, Figure S10A). Very minor changes in the chemical shifts of protons of $\mathrm{C}(1)-\mathrm{OH}$ and $\mathrm{C}(8)-\mathrm{OH}$ groups were observed because $\mathrm{C}(1)-\mathrm{OH}$ and $\mathrm{C}(8)-\mathrm{OH}$ are involved in a strong intramolecular hydrogen bond with the oxygen atom of the $\mathrm{O}=\mathrm{C}(9)$ group. The distance $-(\mathrm{O}) \mathrm{H} \cdots \mathrm{O}(\mathrm{S})$ of the optimized structure was found to be $2.699 \AA$ which indicates that the discrete molecule of DMSO was pushed away from the $\mathrm{C}(1)-\mathrm{OH}$ and $\mathrm{C}(8)-\mathrm{OH}$ groups (Supplementary materials, Figure S10B). This is in excellent agreement with the experimental NMR data that the formation of intramolecular 
hydrogen bond is solvent independent. Similar computational results were obtained when two molecules of DMSO were placed symmetrically in the vicinity of the intramolecular hydrogen bond.

\subsubsection{Comparison Between DFT-Calculated Structures in Solution and Single-Crystal X-ray Method}

The single-crystal X-ray structures of chrysophanol (1) [54], emodin (2) [55], and physcion (3) [56] show that the $\mathrm{C}(1)-\mathrm{OH}$ and $\mathrm{C}(8)-\mathrm{OH}$ groups interact with the $\mathrm{C}(9)=\mathrm{O}$ oxygen atom of the carbonyl group forming an intramolecular hydrogen bond. This is in agreement with our experimental NMR data and DFT-calculated structures. The DFT structures demonstrate excellent agreement with the crystallographic distances of the heavy atoms. Thus, for emodin the $\mathrm{O}(1) \cdots \mathrm{O}(8)$ distances are identical to $\pm 0.006 \AA$ in both structural methods. On the contrary, significant differences were observed for distances involving hydrogen atoms. Thus, the X-ray hydrogen bond distances are $\mathrm{H}(1) \cdots \mathrm{O}(9)=1.831$ $\AA$ and $\mathrm{H}(8) \cdots \mathrm{O}(9)=1.849 \AA$ while in the DFT-calculated structures (with a discrete molecule of DMSO in CPCM-DMSO) the respective distances were found to be $\mathrm{H}(1) \cdots \mathrm{O}(9)=1.6887 \AA$ and $1.6958 \AA$ and $\mathrm{H}(8) \cdots \mathrm{O}(9)=1.6895 \AA$ and $1.6944 \AA$ for conformers $\mathrm{A}_{2}$ and $\mathrm{B}$, respectively. When the X-ray structures were used as input geometries, the DFT-computed ${ }^{1} \mathrm{H}-\mathrm{NMR}$ chemical shifts of $\mathrm{C}(1)-\mathrm{OH}$ and $\mathrm{C}(8)-\mathrm{OH}$ groups were found to strongly deviate from the experimental values by up to $8.84 \mathrm{ppm}$ (Table 4 ). The chemical shifts of the $-\mathrm{CH}$ (aromatics) and $-\mathrm{CH}_{3}$ protons were also found to strongly deviate up to $3.7 \mathrm{ppm}$ from the experimental values.

Table 4. Calculated ${ }^{1} \mathrm{H}-\mathrm{NMR}$ chemical shifts, $\delta_{\text {calc }}$, and $\delta_{\exp }-\delta_{\text {calc }}$ of chrysophanol (1), emodin (2) and physcion (3) using the $\mathrm{X}$-ray structures as input geometries.

\begin{tabular}{|c|c|c|c|}
\hline Compound & Group & $\delta_{X \text {-ray }}$ & $\delta_{\text {exp }}-\delta_{X-\text { ray }}$ \\
\hline \multirow{8}{*}{ Chrysophanol (1) } & $\mathrm{C}(1)-\mathrm{OH}$ & 3.03 & 8.84 \\
\hline & $\mathrm{C}(8)-\mathrm{OH}$ & 3.30 & 8.66 \\
\hline & $\mathrm{C}(4)-\mathrm{H}$ & 5.15 & 2.56 \\
\hline & $\mathrm{C}(5)-\mathrm{H}$ & 4.99 & 2.57 \\
\hline & $\mathrm{C}(3)-\mathrm{H}$ & 4.99 & 2.81 \\
\hline & $\mathrm{C}(7)-\mathrm{H}$ & 4.06 & 3.16 \\
\hline & $\mathrm{C}(2)-\mathrm{H}$ & 4.19 & 3.19 \\
\hline & $\mathrm{C}(6)-\mathrm{CH}_{3}$ & 2.44 & 0.95 \\
\hline \multirow{8}{*}{ Emodin (2) } & $\mathrm{C}(1)-\mathrm{OH}$ & 4.66 & 7.53 \\
\hline & $\mathrm{C}(8)-\mathrm{OH}$ & 4.47 & 7.62 \\
\hline & $\mathrm{C}(5)-\mathrm{H}$ & 5.37 & 2.13 \\
\hline & $\mathrm{C}(4)-\mathrm{H}$ & 4.29 & 2.82 \\
\hline & $\mathrm{C}(7)-\mathrm{H}$ & 4.89 & 2.29 \\
\hline & $\mathrm{C}(2)-\mathrm{H}$ & 3.91 & 2.66 \\
\hline & $\mathrm{C}(3)-\mathrm{OH}$ & 3.91 & 11.41 \\
\hline & $\mathrm{C}(6)-\mathrm{CH}_{3}$ & -1.28 & 3.69 \\
\hline \multirow{8}{*}{ Physcion (3) } & $\mathrm{C}(1)-\mathrm{OH}$ & 7.51 & 4.46 \\
\hline & $\mathrm{C}(8)-\mathrm{OH}$ & 6.21 & 5.96 \\
\hline & $\mathrm{C}(2)-\mathrm{H}$ & 4.51 & 2.37 \\
\hline & $\mathrm{C}(4)-\mathrm{H}$ & 4.84 & 2.36 \\
\hline & $\mathrm{C}(5)-\mathrm{H}$ & 5.62 & 1.91 \\
\hline & $\mathrm{C}(7)-\mathrm{H}$ & 4.80 & 2.4 \\
\hline & $\mathrm{C}(3)-\mathrm{OCH}_{3}$ & 0.61 & 3.30 \\
\hline & $\mathrm{C}(6)-\mathrm{CH}_{3}$ & -1.29 & 3.70 \\
\hline
\end{tabular}

Figure 11 illustrates excellent agreement of the DFT-calculated ${ }^{1} \mathrm{H}-\mathrm{NMR}$ chemical shifts of the energy optimized structures of chrysophanol (1), emodin (2), and physcion (3) with the experimental values. On the contrary, the ${ }^{1} \mathrm{H}-\mathrm{NMR}$ chemical shifts of the $\mathrm{X}$-ray structures, without optimization, of chrysophanol (1), emodin (2), and physcion (3), strongly deviate from the experimental values. The results of the linear regression analysis $\left(R^{2}=0.4147\right.$, intercept $=0.4960$ and slope $\left.=0.4467\right)$ can be compared with the DFT-calculated energy-minimized structures $\left(R^{2}=0.9987\right.$ and 0.9976 , intercept 
$=0.1686$ and 0.2376 , and slope $=1.0138$ and 1.0026 for conformers $\mathrm{A}$ and $\mathrm{B}$, respectively). In the above analysis, the ${ }^{1} \mathrm{H}-\mathrm{NMR}$ chemical shifts of the $\mathrm{C}(3)-\mathrm{OH}$ were not taken into consideration due to significant solvent effects which were analysed in Section 2.2.3. Comparison of the X-ray structures with those obtained with DFT calculations, demonstrates significant differences for all distances involving hydrogen atoms (Supplementary materials, Table S6). Thus, the $\mathrm{X}$-ray O-H bond distances are shorter by 0.152 to $0.132 \AA$ and the $\mathrm{C}-\mathrm{H}$ bond lengths are shorter by 0.133 to $0.100 \AA$ than those obtained with DFT calculations. The above analysis demonstrates that the $\mathrm{X}$-ray structures do not provide reliable results for hydrogen bond and $\mathrm{C}-\mathrm{H}$ bond lengths. It is well known that, due to high electronegativity of the oxygen atom and libration effects, the $\mathrm{O}-\mathrm{H}$ bonds appear too short in X-ray structure determination [1]. This results in poor correlation between X-ray and the more accurate neutron diffraction data $[57,58]$.
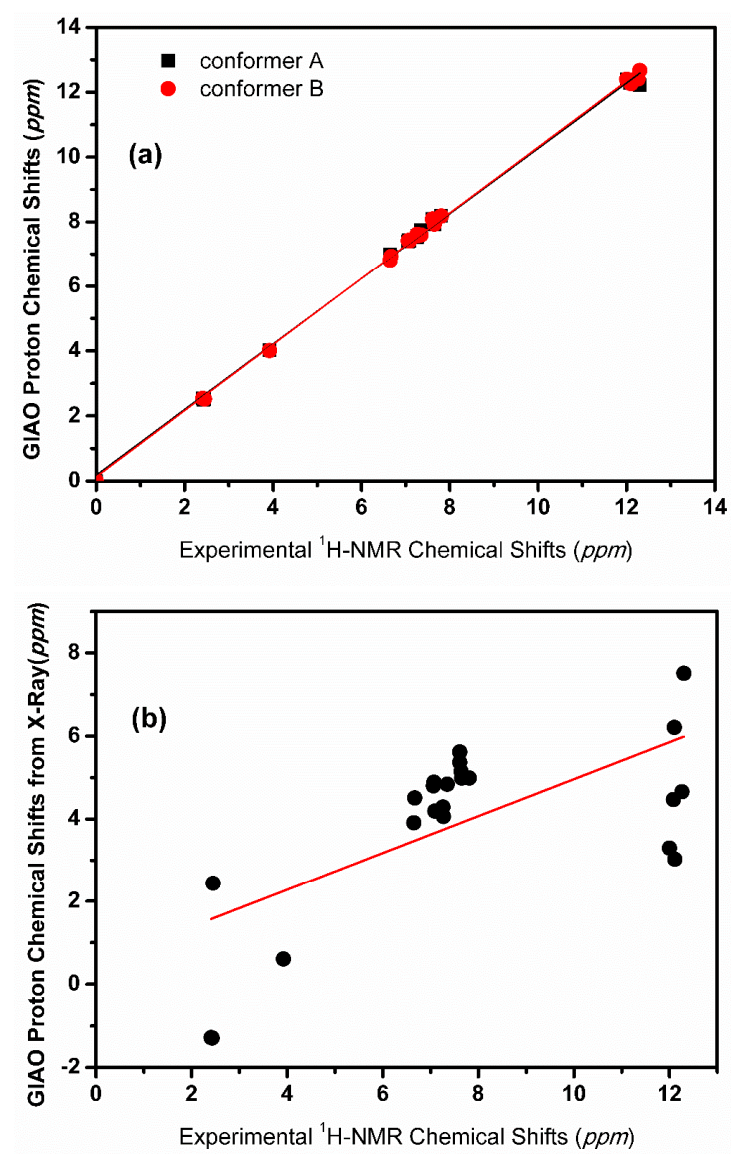

Figure 11. DFT calculated $\left(\delta_{\text {calc, }}\right.$ ppm), at the GIAO_DFT/B3LYP/6-311+G(2d,p) level vs. experimental $\left(\delta_{\text {exp }}, \mathrm{ppm}\right)$ values of NMR chemical shifts of chrysophanol (1), emodin (2), and physcion (3): (a) with optimized structures having a discrete molecule of $\mathrm{CHCl}_{3}\left(\mathrm{CPCM}-\mathrm{CHCl}_{3}\right)$ at the $\mathrm{B} 3 \mathrm{LYP} / 6-31+\mathrm{G}(\mathrm{d})$ level and $(\mathbf{b})$ by using $\mathrm{X}$-ray structures as input geometries $\left(\delta_{\text {calc, } x \text {-ray }}\right)$ at the same level of theory $\left(\mathrm{CPCM}-\mathrm{CHCl}_{3}\right)$.

Differences between the X-ray and DFT-calculated structures have also been observed in the conformation of the substituents. Thus, a torsion angle $\mathrm{C}(5)-\mathrm{C}(6)-\mathrm{C}\left(6^{\prime}\right)-\mathrm{H}\left(6^{\prime}\right)=-164^{\circ}$ was observed in the X-ray structure of physcion (3) [56] which deviates from the DFT value of $-179.75^{\circ}$, due to $\pi$-stacking interaction of the hydrogen atom with an aromatic system. In the X-ray structure of chrysophanol (1) [54] a particular conformer could not be observed due to fast rotation of the $\mathrm{CH}_{3}-$ group. In the $\mathrm{X}$-ray structure of physcion (1) [56] the $-\mathrm{OCH}_{3}$ group adopts conformation $\mathrm{A}$, while in the DFT-calculated structure, conformer B is the most stable one. 


\section{Materials and Methods}

\subsection{Chemicals}

Chrysophanol (1), emodin (2), and physcion (3) were obtained from Molecular Data Bank, ICCBS, University of Karachi. DMSO- $\mathrm{d}_{6}$, acetone- $\mathrm{d}_{6}$, and $\mathrm{CDCl}_{3}$ were purchased from Armar Chemicals AG, Dottingen, Switzerland and TFA from Sigma-Aldrich, Darmstadt, Germany.

\section{2. $N M R$}

NMR experiments were performed on Bruker AV-spectrometers (400, 500, and $800 \mathrm{MHz}$, Bruker, Billerica, MA, USA) equipped with TXI cryoprobes. Samples were dissolved in $0.6 \mathrm{~mL}$ of deuterated solvent and transferred to $5 \mathrm{~mm}$ NMR tubes. Chemical shifts were measured with reference to the residual proton signal of the incompletely deuterated solvent. 1D selective TOCSY and NOE and 2D ${ }^{1} \mathrm{H}_{-}{ }^{13} \mathrm{C}$ HSQC and HMBC experiments were carried out using standard pulse program of Bruker.

\subsection{Computational Methods}

The computational study was performed by using the Gaussian 09 with the DFT method [52]. The structures were minimized/optimized by using five functionals and three basis sets: B3LYP/6-31 + G(d), $\omega B 97 X D / 6-31+G(d)$, APFD/6-31 + G(d), M06-2X/Def2TZVP, and TPSSh/TZVP. The ${ }^{1} \mathrm{H}-\mathrm{NMR}$ chemical shifts were calculated with the GIAO method by using the B3LYP/6-311 + G(2d,p) level with the CPCM (conductor like polarizable continuum model) [53]. Computations were also performed in the case of emodin (2) by the inclusion of discrete solvent molecules of DMSO, acetone, and $\mathrm{CHCl}_{3}$. The scanning of torsional and dihedral angles was performed by using the redundant coordinates in Gaussian 09. The optimized geometries were verified as minimized geometries by performing the frequency calculation at the same level (zero imaginary frequencies). TMS was used as reference for the computed ${ }^{1} \mathrm{H}-\mathrm{NMR}$ chemical shifts and was optimised at the same level.

\section{Conclusions}

From the data reported herein, it can be concluded that:

1. Excellent linear correlation can be obtained between experimental and DFT-calculated ${ }^{1} \mathrm{H}-\mathrm{NMR}$ chemical shifts even with computationally less demanding level of theory.

2. Inclusion of discrete solvent molecules induces a minor effect on the computed ${ }^{1} \mathrm{H}-\mathrm{NMR}$ chemical shifts of the intramolecular hydrogen bond, but shows a significant effect on the ${ }^{1} \mathrm{H}-\mathrm{NMR}$ chemical shifts of the $\mathrm{C}(3)-\mathrm{OH}$ which participates in intermolecular solute-solvent hydrogen bond; this results in excellent agreement with the experimental ${ }^{1} \mathrm{H}-\mathrm{NMR}$ chemical shifts.

3. The ${ }^{1} \mathrm{H}-\mathrm{NMR}$ chemical shifts of the $\mathrm{OH}$ groups which participate in intramolecular hydrogen bond are dependent on the conformational state of substituents and, thus, can be used as molecular sensors in conformational analysis.

4. The use of X-ray structures as input geometries results in ${ }^{1} \mathrm{H}$-NMR chemical shifts which strongly deviate from the experimental values and no functional dependence could be obtained.

5. Comparison of the most important intramolecular data of the DFT-calculated and the X-ray structures demonstrate very good agreement with distances involving heavy atoms but significant differences for distances involving hydrogen atoms, most notably the intramolecular hydrogen bond and C-H bond lengths which deviate by 0.152 to $0.132 \AA$ and 0.133 to $0.100 \AA$, respectively. Further differences have been found in the conformational state of the $-\mathrm{CH}_{3},-\mathrm{OCH}_{3}$, and -OH groups.

The great sensitivity, therefore, of ${ }^{1} \mathrm{H}-\mathrm{NMR}$ chemical shifts to hydrogen bond properties, solute-solvent interactions, torsion angle, and $\mathrm{C}-\mathrm{H}$ bond lengths can provide an excellent method for obtaining high-resolution structures in solution. 
Supplementary Materials: Supplementary Materials are available online. ${ }^{1} \mathrm{H}-{ }^{13} \mathrm{C}$ HMBC spectrum, calculated ${ }^{1} \mathrm{H}$ NMR chemical shifts, electronic energies and optimized geometries of conformers, molecular orbitals, ${ }^{1} \mathrm{H}$ NMR chemical shifts at various temperatures, calculated ${ }^{1} \mathrm{H}$ NMR chemical shifts as a function of torsion angle, comparison of DFT calculated structural data with single-crystal X-ray structures, Cartesian coordinates.

Author Contributions: S.H.M. performed NMR experiments and DFT calculations; P.C.V. performed DFT calculations and contributed to the writing of the manuscript; M.G.S. performed DFT calculations, conceived and designed the study, and contributed to the writing of the manuscript; A.-t.-W., I.M.C., and I.P.G. conceived and designed the study and contributed to the writing of the manuscript. All authors read and approved the final manuscript.

Funding: This research received no external funding.

Conflicts of Interest: The authors declare that they have no conflict of interest.

\section{References}

1. Massa, W. Crystal Structure Determination; Springer: Berlin/Heidelberg, Germany, 2004.

2. Smart, L.E.; Moore, E.A. Solid State Chemistry: An Introduction; Taylor \& Francis: London, UK, 2005.

3. Jeffrey, G.A.; Sanger, S.W. Hydrogen Bonding in Biological Structures; Springer: Berlin, Germany, 1991.

4. Yee, A.A.; Savchenko, A.; Ignachenko, A.; Lukin, I.; Xu, X.; Skarina, T.; Evdokimova, E.; Liu, C.S.; Semesi, A.; Guido, V.; et al. NMR and X-ray crystallography, complementary tools in structural proteomics of small proteins. J. Am. Chem. Soc. 2005, 127, 16512-16517. [CrossRef] [PubMed]

5. Szymczyna, B.R.; Taurog, R.E.; Young, M.J.; Snyder, J.C.; Johnson, J.E.; Williamson, J.R. Synergy of NMR, computation, and X-ray crystallography for structural biology. Structure 2009, 17, 499-507. [CrossRef] [PubMed]

6. Günther, H. NMR Spectroscopy: Basic Principles, Concepts and Applications in Chemistry; Wiley VCH: Weinheim, Germany, 2013.

7. Frey, P.A.; Whitt, S.A.; Tobin, J.B. A low-barrier hydrogen bond in the catalytic triad of serine proteases. Science 1994, 264, 1927-1930. [CrossRef] [PubMed]

8. Bertolasi, V.; Gilli, P.; Ferretti, V.; Gilli, G. Intramolecular O-H $\cdots$ O hydrogen bonds assisted by resonance. Correlation between crystallographic data and ${ }^{1} \mathrm{H}$ NMR chemical shifts. J. Chem. Soc. Perkin Trans. 1997, 2, 945-952. [CrossRef]

9. Harris, T.K.; Mildvan, A.S. High-precision measurement of hydrogen bond lengths in proteins by nuclear magnetic resonance methods. Proteins Struct. Funct. Bioinf. 1999, 35, 275-282. [CrossRef]

10. Baxter, N.J.; Williamson, M.P. Temperature dependence of ${ }^{1} \mathrm{H}$ chemical shifts in proteins. J. Biomol. NMR 1997, 9, 359-369. [CrossRef] [PubMed]

11. Dyson, H.J.; Rance, M.; Houghten, R.A.; Lerner, R.A.; Wright, P.E. Folding of immunogenic peptide fragments of proteins in water solution: I. Sequence requirements for the formation of a reverse turn. J. Mol. Biol. 1988, 201, 161-200. [CrossRef]

12. Neuhaus, D.; Williamson, M.P. The Nuclear Overhauser Effect in Structural and Conformational Analysis, 2nd ed.; Willey-VCH: New York, NY, USA, 2000.

13. Vögeli, B. The nuclear Overhauser effect from a quantitative perspective. Prog. Nucl. Magn. Reson. Spectrosc. 2014, 78, 1-46. [CrossRef] [PubMed]

14. Dingley, A.J.; Grzesiek, S. Direct observation of hydrogen bonds in nucleic acid base pairs by internucleotide 2JNN couplings. J. Am. Chem. Soc. 1998, 120, 8293-8297. [CrossRef]

15. Grzesiek, S.; Cordier, F.; Dingley, A.J. Scalar couplings across hydrogen bonds. Methods Enzymol. 2002, 338, 111-133.

16. De Dios, A.C. Ab initio calculations of the NMR chemical shift. Prog. Nucl. Magn. Reson. Spectrosc. 1996, 29, 229-278. [CrossRef]

17. Bifulco, G.; Dambruoso, P.; Gomez-Paloma, L.; Riccio, R. Determination of relative configuration in organic compounds by NMR spectroscopy and computational methods. Chem. Rev. 2007, 107, 3744-3779. [CrossRef]

18. Barone, V.; Improta, R.; Rega, N. Quantum mechanical computations and spectroscopy: From small rigid molecules in the gas phase to large flexible molecules in solution. Acc. Chem. Res. 2008, 41, 605-616. [CrossRef] [PubMed]

19. Mulder, F.A.; Filatov, M. NMR chemical shift data and ab initio shielding calculations: Emerging tools for protein structure determination. Chem. Soc. Rev. 2010, 39, 578-590. [CrossRef] [PubMed] 
20. Lodewyk, M.W.; Siebert, M.R.; Tantillo, D.J. Computational prediction of ${ }^{1} \mathrm{H}$ and ${ }^{13} \mathrm{C}$ chemical shifts: A useful tool for natural product, mechanistic, and synthetic organic chemistry. Chem. Rev. 2012, 112, 1839-1862. [CrossRef] [PubMed]

21. Bagno, A.; Rastrelli, F.; Saielli, G. Toward the complete prediction of the ${ }^{1} \mathrm{H}$ and ${ }^{13} \mathrm{C}$ NMR spectra of complex organic molecules by DFT methods: Application to natural substances. Chem. Eur. J. 2006, 12, 5514-5525. [CrossRef]

22. Rychnovsky, S.D. Predicting NMR spectra by computational methods: Structure revision of hexacyclinol. Org. Lett. 2006, 8, 2895-2898. [CrossRef]

23. Smith, S.G.; Goodman, J.M. Assigning the stereochemistry of pairs of diastereoisomers using GIAO NMR shift calculation. J. Org. Chem. 2009, 74, 4597-4607. [CrossRef]

24. Saielli, G.; Nicolaou, K.C.; Ortiz, A.; Zhang, H.; Bagno, A. Addressing the stereochemistry of complex organic molecules by density functional theory-NMR: Vannusal B in retrospective. J. Am. Chem. Soc. 2011, 133, 6072-6077. [CrossRef]

25. Tarazona, G.; Benedit, G.; Fernández, R.; Pérez, M.; Rodriguez, J.; Jiménez, C.; Cuevas, C. Can stereoclusters separated by two methylene groups be related by DFT studies? The case of the cytotoxic meroditerpenes halioxepines. J. Nat. Prod. 2018, 81, 343-348. [CrossRef]

26. Siskos, M.G.; Tzakos, A.G.; Gerothanassis, I.P. Accurate ab initio calculations of O-H $\cdots$ O and O-H $\cdots-\mathrm{O}$ proton chemical shifts: Towards elucidation of the nature of the hydrogen bond and prediction of hydrogen bond distances. Org. Biomol. Chem. 2015, 13, 8852-8868. [CrossRef] [PubMed]

27. Siskos, M.G.; Choudhary, M.I.; Tzakos, A.G.; Gerothanassis, I.P. ${ }^{1}$ H NMR chemical shift assignment, structure and conformational elucidation of hypericin with the use of DFT calculations-The challenge of accurate positions of labile hydrogens. Tetrahedron 2016, 72, 8287-8293. [CrossRef]

28. Siskos, M.G.; Choudhary, M.I.; Gerothanassis, I.P. Hydrogen atomic positions of O-H...O hydrogen bonds in solution and in the solid state: The synergy of quantum chemical calculations with $1 \mathrm{H}-\mathrm{NMR}$ chemical shifts and X-ray diffraction methods. Molecules 2017, 22, 415. [CrossRef] [PubMed]

29. Siskos, M.G.; Choudhary, M.I.; Gerothanassis, I.P. Refinement of labile hydrogen positions based on DFT calculations of ${ }^{1} \mathrm{H}$ NMR chemical shifts: Comparison with X-ray and neutron diffraction methods. Org. Biomol. Chem. 2017, 15, 4655-4666. [CrossRef] [PubMed]

30. Siskos, M.G.; Choudhary, M.I.; Gerothanassis, I.P. DFT-calculated structures based on ${ }^{1}$ H NMR chemical shifts in solution vs. structures solved by single-crystal X-ray and crystalline-sponge methods: Assessing specific sources of discrepancies. Tetrahedron 2018, 74, 4728-4737. [CrossRef]

31. Torralba, M.P.; Sanz, D.; Claramunt, R.M.; Alkorta, I.; Dardonville, C.; Elguero, J. The structure of fosfomycin salts in solution and in the solid state by nuclear magnetic resonance spectroscopy and DFT calculations. Tetrahedron 2018, 74, 3937-3942. [CrossRef]

32. Lee, M.S.; Cha, E.Y.; Sul, J.Y.; Song, I.S.; Kim, J.Y. Chrysophanic acid blocks proliferation of colon cancer cells by inhibiting EGFR/mTOR pathway. Phytotherapy Res. 2011, 25, 833-837. [CrossRef]

33. Dong, X.; Fu, J.; Yin, X.; Cao, S.; Li, X.; Huyiligeqi, L.; Ni, J. Emodin: A review of its pharmacology, toxicity and pharmacokinetics. Phytotherapy Res. 2016, 30, 1207-1218. [CrossRef] [PubMed]

34. Hsu, S.C.; Chung, J.G. Anticancer potential of emodin. BioMedicine 2012, 2, 108-116. [CrossRef]

35. Wijesekara, I.; Zhang, C.; Van Ta, Q.; Vo, T.S.; Li, Y.X.; Kim, S.K. Physcion from marine-derived fungus Microsporum sp. induces apoptosis in human cervical carcinoma HeLa cells. Microbiol. Res. 2014, 169, 255-261. [CrossRef]

36. Perrin, C.L.; Nielson, J.B. "Strong" hydrogen bonds in chemistry and biology. Ann. Rev. Phys. Chem. 1997, 48, 511-544. [CrossRef] [PubMed]

37. Exarchou, V.; Troganis, A.; Gerothanassis, I.P.; Tsimidou, M.; Boskou, D. Do strong intramolecular hydrogen bonds persist in aqueous solution? Variable temperature gradient ${ }^{1} \mathrm{H},{ }^{1} \mathrm{H}-{ }^{13} \mathrm{C}$ GE-HSQC and GE-HMBC NMR studies of flavonols and flavones in organic and aqueous mixtures. Tetrahedron 2002, 58, 7423-7429. [CrossRef]

38. Charisiadis, P.; Exarchou, V.; Troganis, A.N.; Gerothanassis, I.P. Exploring the "forgotten"-OH NMR spectral region in natural products. Chem. Commun. 2010, 46, 3589-3591. [CrossRef] [PubMed]

39. Charisiadis, P.; Primikyri, A.; Exarchou, V.; Tzakos, A.G.; Gerothanassis, I.P. Unprecedented ultra-highresolution hydroxy group ${ }^{1} \mathrm{H}$ NMR spectroscopic analysis of plant extracts. J. Nat. Prod. 2011, 74, 2462-2466. [CrossRef] [PubMed] 
40. Kontogianni, V.G.; Charisiadis, P.; Primikyri, A.; Pappas, C.G.; Exarchou, V.; Tzakos, A.G.; Gerothanassis, I.P. Hydrogen bonding probes of phenol-OH groups. Org. Biomol. Chem. 2013, 11, 1013-1025. [CrossRef] [PubMed]

41. Siskos, M.G.; Kontogianni, V.G.; Tsiafoulis, C.G.; Tzakos, A.G.; Gerothanassis, I.P. Investigation of solute-solvent interactions in phenol compounds: Accurate ab initio calculations of solvent effects on ${ }^{1}$ H NMR chemical shifts. Org. Biomol. Chem. 2013, 11, 7400-7411. [CrossRef] [PubMed]

42. Charisiadis, P.; Kontogianni, V.; Tsiafoulis, C.; Tzakos, A.; Siskos, M.; Gerothanassis, I.P. ${ }^{1}$ H-NMR as a structural and analytical tool of intra-and intermolecular hydrogen bonds of phenol-containing natural products and model compounds. Molecules 2014, 19, 13643-13682. [CrossRef] [PubMed]

43. Aliev, A.E.; Harris, K.D.M. Probing Hydrogen Bonding in Solids Using Solid State NMR Spectroscopy. In Supramolecular Assembly via Hydrogen Bonds I; Springer: Berlin/Heidelberg, Germany, 2004.

44. Lomas, J.S. ${ }^{1} \mathrm{H}$ NMR spectra of butane-1, 4-diol and other 1, 4-diols: DFT calculation of shifts and coupling constants. Magn. Reson. Chem. 2014, 52, 87-97. [CrossRef]

45. Abraham, M.H.; Abraham, R.J.; Acree, W.E.; Aliev, A.E.; Leo, A.J.; Whaley, W.L. An NMR method for the quantitative assessment of intramolecular hydrogen bonding; application to physicochemical, environmental, and biochemical properties. J. Org. Chem. 2014, 79, 11075-11083. [CrossRef] [PubMed]

46. Lomas, J.S. ${ }^{1} \mathrm{H}$ NMR spectra of alcohols in hydrogen bonding solvents: DFT/GIAO calculations of chemical shifts. Magn. Reson. Chem. 2016, 54, 28-38. [CrossRef]

47. Kubica, D.; Molchanov, S.; Gryff-Keller, A. Solvation of uracil and its derivatives by DMSO: A DFT-supported ${ }^{1}$ H NMR and ${ }^{13}$ C NMR study. J. Phys. Chem. A 2017, 121, 1841-1848. [CrossRef] [PubMed]

48. Tolstoy, P.M.; Koeppe, B.; Denisov, G.S.; Limbach, H.H. Combined NMR and UV-vis spectroscopy in the solution state: Study of the geometries of strong $\mathrm{OHO}$ hydrogen bonds of phenols with carboxylic acids. Angew. Chem. Int. Ed. 2009, 48, 5745-5747. [CrossRef] [PubMed]

49. Bolvig, S.; Hansen, P.E. Isotope effects on chemical shifts as an analytical tool in structural studies of intramolecular hydrogen bonded compounds. Curr. Org. Chem. 2000, 4, 19-54. [CrossRef]

50. Hansen, P. Isotope effects on chemical shifts in the study of intramolecular hydrogen bonds. Molecules 2015, 20, 2405-2424. [CrossRef]

51. Stevens, S.E.; Sugawara, N.; Bonora, G.M.; Toniolo, C. Conformational analysis of linear peptides. 3. Temperature dependence of NH chemical shifts in chloroform. J. Am. Chem. Soc. 1980, 102, 7048-7050. [CrossRef]

52. Frisch, M.J.; Trucks, G.W.; Schlegel, H.B.; Scuseria, G.E.; Robb, M.A.; Cheeseman, J.R.; Scalmani, G.; Barone, V.; Mennucci, B.; Petersson, G.A.; et al. Gaussian 0.9, Revision. B.01; Gaussian, Inc.: Wallingford, CT, USA, 2010.

53. Klein, R.A.; Mennucci, B.; Tomasi, J. Ab initio calculations of ${ }^{17} \mathrm{O}$ NMR-chemical shifts for water. The limits of PCM theory and the role of hydrogen-bond geometry and cooperativity. J. Phys. Chem. A 2004, 108, 5851-5863. [CrossRef]

54. Argay, G.; Kalman, A.; Kovacevic, N.; Grubisic, D.; Ribar, B. Crystal structure of 1,8-dihydroxy-3-methyl-9, 10-anthracendion. Z. Kristallogr. 1996, 211, 723-724.

55. Zhu, J.C.; Liang, Y.; Wang, H.S.; Pan, Y.M.; Zhang, Y. 1,3,8-trihydroxy-6-methylanthraquinone monohydrate. Acta Cryst. E 2007, 63, o233-o235. [CrossRef]

56. Hopf, H.; Jones, P.G.; Goclik, E.; Aust, P.; Rödiger, J. A new polymorph of physcion. Acta Cryst. C 2012, 68, o317-o319. [CrossRef]

57. Deringer, V.L.; Hoepfner, V.; Dronskowski, R. Accurate hydrogen positions in organic crystals: Assessing a quantum-chemical aide. Cryst. Growth Des. 2012, 12, 1014-1021. [CrossRef]

58. Rybarczyk-Pirek, A.J.; Malecka, M.; Palusiak, M. Use of quantum theory of atoms in molecules in the search of appropriate hydrogen atom locations in X-ray diffraction based studies. Cryst. Growth Des. 2016, 16, 6841-6848. [CrossRef]

Sample Availability: Samples of the compounds chrysophanol (1), emodin (2), and physcion (3) are available from the authors. 